Cochrane Database of Systematic Reviews

\title{
Single dose oral celecoxib for acute postoperative pain in adults
} (Review)

Derry S, Moore RA

Derry S, Moore RA.

Single dose oral celecoxib for acute postoperative pain in adults.

Cochrane Database of Systematic Reviews 2013, Issue 10. Art. No.: CD004233.

DOI: 10.1002/14651858.CD004233.pub4.

www.cochranelibrary.com 
TABLE OF CONTENTS

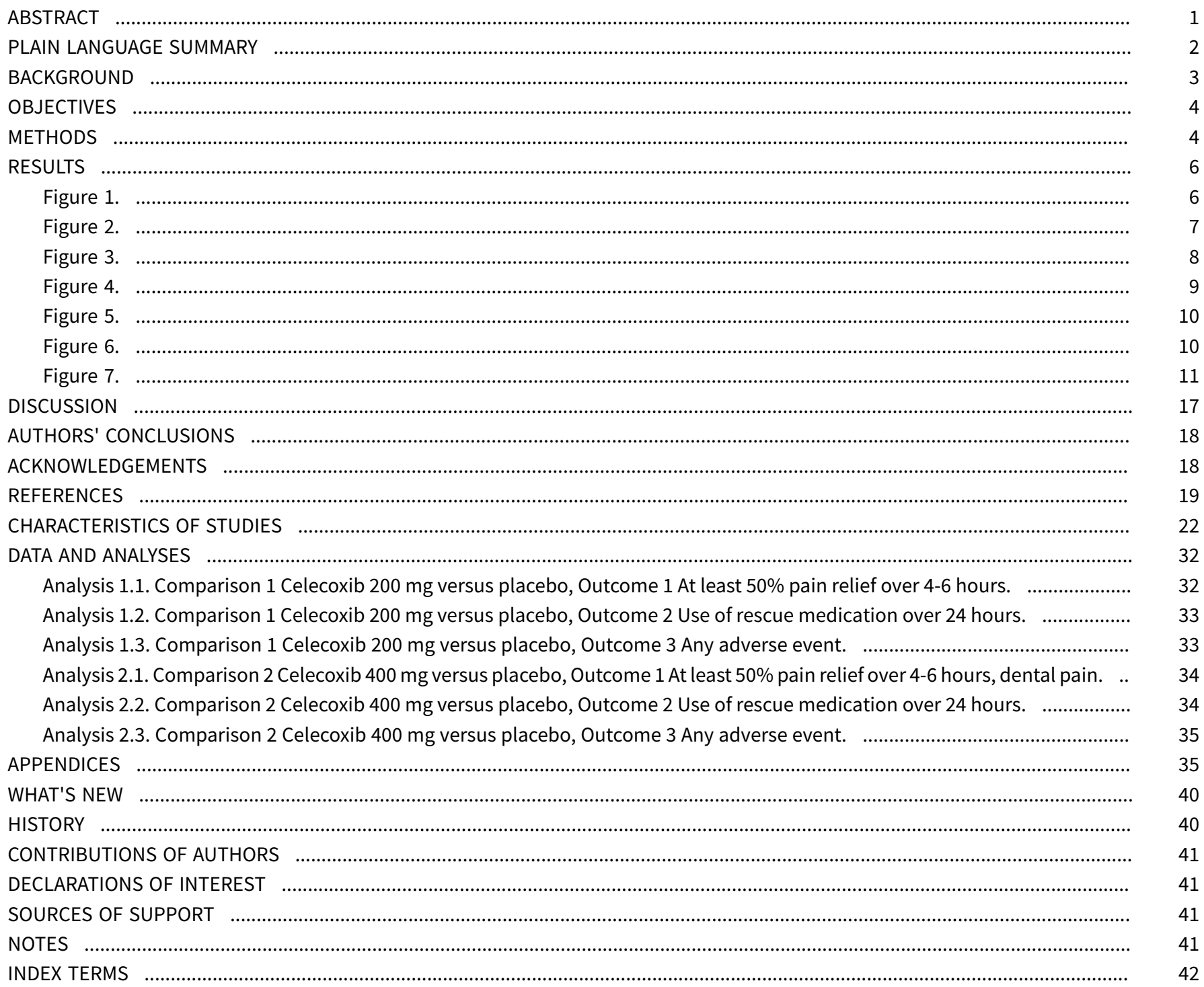


[Intervention Review]

\section{Single dose oral celecoxib for acute postoperative pain in adults}

Sheena Derry ${ }^{1}$, R Andrew Moore 2

1Oxford, UK. 2Plymouth, UK

Contact: Sheena Derry, Oxford, Oxfordshire, UK. sheena.derry@retired.ox.ac.uk.

Editorial group: Cochrane Pain, Palliative and Supportive Care Group.

Publication status and date: Stable (no update expected for reasons given in 'What's new'), published in Issue 5, 2019.

Citation: Derry S, Moore RA. Single dose oral celecoxib for acute postoperative pain in adults. Cochrane Database of Systematic Reviews 2013, Issue 10. Art. No.: CD004233. DOI: 10.1002/14651858.CD004233.pub4.

Copyright @ 2019 The Cochrane Collaboration. Published by John Wiley \& Sons, Ltd.

\section{A B S T R A C T}

\section{Background}

This is an update of a review first published in The Cochrane Library in Issue 4, 2008, and updated in Issue 3, 2012. Celecoxib is a selective cyclo-oxygenase-2 (COX-2) inhibitor usually prescribed for the relief of chronic pain in osteoarthritis and rheumatoid arthritis. Celecoxib is believed to be associated with fewer upper gastrointestinal adverse effects than conventional non-steroidal anti-inflammatory drugs (NSAIDs). Its effectiveness in acute pain was demonstrated in the earlier reviews.

\section{Objectives}

To assess analgesic efficacy and adverse effects of a single oral dose of celecoxib for moderate to severe postoperative pain in adults.

\section{Search methods}

We searched the Cochrane Central Register of Controlled Trials (CENTRAL), MEDLINE, EMBASE, the Oxford Pain Database, and ClinicalTrials.gov. The most recent search was to 31 May 2013.

\section{Selection criteria}

We included randomised, double-blind, placebo-controlled trials (RCTs) of adults prescribed any dose of oral celecoxib or placebo for acute postoperative pain.

\section{Data collection and analysis}

Two review authors assessed studies for quality and extracted data. We converted summed pain relief (TOTPAR) or pain intensity difference (SPID) into dichotomous information, yielding the number of participants with at least $50 \%$ pain relief over four to six hours. We used this to calculate the relative benefit (RB) and number needed to treat to benefit (NNT), for one patient to achieve at least $50 \%$ of maximum pain relief with celecoxib who would not have done so with placebo. We used information on use of rescue medication to calculate the proportion of participants requiring rescue medication and the weighted mean of the median time to use.

\section{Main results}

Ten studies (1785 participants) met the inclusion criteria. The two new studies in this update had been identified in the earlier update, but data were not available. There remain three potentially relevant unpublished studies for which data are not available at this time.

The NNT for celecoxib $200 \mathrm{mg}$ and $400 \mathrm{mg}$ compared with placebo for at least $50 \%$ of maximum pain relief over four to six hours was 4.2 (95\% confidence interval $(\mathrm{Cl}) 3.4$ to 5.6$)$ and $2.6(95 \% \mathrm{Cl} 2.3$ to 3.0$)$ respectively. The median time to use of rescue medication was 6.6 hours with celecoxib $200 \mathrm{mg}$, 8.4 hours with celecoxib $400 \mathrm{mg}$, and 2.3 hours with placebo. The proportion of participants requiring rescue medication over 24 hours was $74 \%$ with celecoxib $200 \mathrm{mg}, 63 \%$ for celecoxib $400 \mathrm{mg}$, and $91 \%$ for placebo. The NNT to prevent one patient using rescue medication was $4.8(95 \% \mathrm{Cl} 3.5$ to 7.7$)$ and $3.5(95 \% \mathrm{Cl} 2.9$ to 4.6$)$ for celecoxib $200 \mathrm{mg}$ and 400 mg respectively. Adverse events 
were generally mild to moderate in severity, and were experienced by a similar proportion of participants in the celecoxib and placebo groups. One serious adverse event that was probably related to celecoxib was reported.

\section{Authors' conclusions}

Single-dose oral celecoxib is an effective analgesic for postoperative pain relief. Indirect comparison suggests that the $400 \mathrm{mg}$ dose has similar efficacy to ibuprofen $400 \mathrm{mg}$.

\section{PLAIN LANGUAGE SUMMARY}

\section{Single-dose oral celecoxib for postoperative pain}

Acute pain is often felt soon after injury. Most people who have surgery have moderate or severe pain afterwards. People with pain are used to test pain killers. They have often had wisdom teeth removed. The pain is often treated with pain killers given by mouth. Results can then be applied to other forms of acute pain.

A series of reviews has looked at how good pain killers are. This review looked at a drug called celecoxib. Celecoxib is most often used for chronic pain caused by arthritis and is one of a group of medicines called non-steroidal anti-inflammatory drugs (NSAIDs). When used for a long time, celecoxib has fewer side effects associated with the digestive system than other NSAIDs.

This review assessed information from 10 studies which used celecoxib for acute pain. Just over 3 in 10 people (33\%) taking celecoxib $200 \mathrm{mg}$, and over 4 in $10(43 \%)$ taking celecoxib $400 \mathrm{mg}$, experienced good pain relief (at least 50\%) compared to about 1 in 10 (range $1 \%$ to $11 \%$ ) with placebo. Comparing the results of the different studies showed that the $200 \mathrm{mg}$ dose of celecoxib was at least as good as aspirin 600 to $650 \mathrm{mg}$ and paracetamol (acetaminophen) $1000 \mathrm{mg}$ for relieving postoperative pain, while a $400 \mathrm{mg}$ dose was at least as good as ibuprofen $400 \mathrm{mg}$. The number of people who experienced negative (adverse) reactions was similar for celecoxib and placebo, and stopping the medication due to these adverse reactions also occurred at similar rates. One serious adverse event, muscle breakdown (rhabdomyolysis), was probably related to celecoxib. 


\section{B A C K G R O U N D}

This is an update of a review first published in The Cochrane Library in Issue 4, 2008 and updated in Issue 3, 2012.

\section{Description of the condition}

Acute pain occurs as a result of tissue damage, either accidentally due to an injury or as a result of surgery. Acute postoperative pain is a manifestation of inflammation due to tissue injury. The management of postoperative pain and inflammation is a critical component of patient care.

This is one of a series of reviews whose aim is to present evidence for relative analgesic efficacy through indirect comparisons with placebo, in very similar trials performed in a standard manner, with very similar outcomes, and over the same duration. Such relative analgesic efficacy does not in itself determine choice of drug for any situation or patient, but guides policy-making at the local level. The series includes well-established analgesics such as paracetamol (Toms 2008), naproxen (Derry C 2009a), diclofenac (Derry P 2009), and ibuprofen (Derry C 2009b), and newer cyclooxygenase-2 selective analgesics such as lumiracoxib (Roy 2010) and etoricoxib (Clarke 2012). An overview brings together the results from all the individual drug reviews (Moore 2011a).

\section{Acute pain trials}

Single-dose trials in acute pain are commonly short in duration, rarely lasting longer than 12 hours. The numbers of participants are small, allowing no reliable conclusions to be drawn about safety. To show that the analgesic is working it is necessary to use placebo (McQuay 2005). There are clear ethical considerations in doing this. These ethical considerations are answered by using acute pain situations where the pain is expected to go away, and by providing additional analgesia, commonly called rescue analgesia, if the pain has not diminished after about an hour. This is reasonable because not all participants given an analgesic will have significant pain relief. Approximately $18 \%$ of participants given placebo will have significant pain relief (Moore 2006), and up to 50\% may have inadequate analgesia with active medicines. The use of additional or rescue analgesia is hence important for all participants in the trials.

Clinical trials measuring the efficacy of analgesics in acute pain have been standardised over many years. Trials have to be randomised and double-blind. Typically, in the first few hours or days after an operation, patients develop pain that is moderate to severe in intensity and will then be given the test analgesic or placebo. Pain is measured using standard pain intensity scales immediately before the intervention, and then using pain intensity and pain relief scales over the following four to six hours for shorteracting drugs, and up to 12 or 24 hours for longer-acting drugs. Pain relief of half the maximum possible pain relief or better (at least $50 \%$ pain relief) is typically regarded as a clinically useful outcome. For patients given rescue medication it is usual for no additional pain measurements to be made, and for all subsequent measures to be recorded as the initial pain intensity or baseline (zero) pain relief (baseline observation carried forward). This process ensures that analgesia from the rescue medication is not wrongly ascribed to the test intervention. In some trials the last observation is carried forward, which gives an inflated response for the test intervention compared to placebo, but the effect has been shown to be negligible over four to six hours (Moore 2005a). Patients usually remain in the hospital or clinic for at least the first six hours following the intervention, with measurements supervised, although they may then be allowed home to make their own measurements in trials of longer duration.

Knowing the relative efficacy of different analgesic drugs at various doses can be helpful. Results from completed reviews of many different analgesics have been brought together to facilitate (indirect) comparisons in a recently published acute pain overview (Moore 2011a), and analgesics relevant to dentistry are discussed in Barden 2004 and Derry 2011.

\section{Description of the intervention}

Selective cyclo-oxygenase-2 inhibitors or 'coxibs' were developed to address the problem of upper gastrointestinal bleeding associated with traditional non-steroidal anti-inflammatory drugs (NSAIDs) (Hawkey 2001). Celecoxib (brand names Celebrex, Celebra, Onsenal) was one of the first of the new generation of NSAIDs known as selective cyclo-oxygenase-2 inhibitors (COX-2 inhibitors) or 'coxibs', and Celebrex ${ }^{\circledR}$ is currently licensed for the relief of osteoarthritis and rheumatoid arthritis pain in many countries around the world, including the United Kingdom and United States of America. The drug is licensed for acute pain in the United States and some other regulatory areas, but not in the United Kingdom. It is available by prescription only in many countries, as $50 \mathrm{mg}, 100 \mathrm{mg}, 200 \mathrm{mg}$, or $400 \mathrm{mg}$ capsules, but generic formulations are available in some parts of Asia and the Far East where patents have expired. It is most often used for chronic painful conditions, such as osteoarthritis, where the usual adult dose is $100 \mathrm{mg}$ to $200 \mathrm{mg}$ twice daily. In acute painful conditions, such as postoperative pain and menstrual pain, up to $400 \mathrm{mg}$ is sometimes given as a single or starting dose. In primary care in England in 2010, there were 460,000 prescriptions for celecoxib, with almost equal numbers for the $100 \mathrm{mg}$ and $200 \mathrm{mg}$ doses (PACT 2010).

\section{How the intervention might work}

NSAIDs have pain-relieving, antipyretic, and anti-inflammatory properties, and are thought to relieve pain by inhibiting cyclooxygenases and thus the production of prostaglandins (Hawkey 1999). Prostaglandins occur throughout body tissues and fluids and act to stimulate pain nerve endings and promote or inhibit the aggregation of blood platelets. Cyclo-oxygenase has at least two isoforms: COX-1 and COX-2. COX-1 is constitutive while COX-2 is induced at sites of inflammation and produces the prostaglandins involved in inflammatory responses and pain mediation (GrahameSmith 2002). Unlike traditional NSAIDs such as ibuprofen and ketoprofen, the coxibs are selective inhibitors, blocking primarily the action of COX-2, providing pain relief and causing fewer gastrointestinal effects (Moore 2005b). In addition, they should not precipitate bleeding events through inhibition of platelet aggregation (Straube 2005).

In common with other NSAIDs, COX-2 inhibitors can give rise to fluid retention and renal damage (Garner 2002), so particular caution is needed in the elderly (Hawkey 2001). COX-2 inhibitors have been implicated in increased cardiovascular problems in long-term use, but this is complicated by differences in their pharmacology and pharmacokinetics (Patrono 2009). Moreover, recent evidence 
indicates that prior cardiac damage may be a more important trigger than any particular drug or class of drug (Ruff 2011).

\section{OB JECTIVES}

To assess analgesic efficacy and the adverse effects of a single oral dose of celecoxib for moderate to severe postoperative pain in adults, using methods that permit comparison with other analgesics evaluated in the same way, and using wider criteria of efficacy as recommended by an in-depth study at the individual patient level (Moore 2005a; Moore 2011b).

\section{METHODS}

\section{Criteria for considering studies for this review Types of studies}

We included studies if they were full publications of doubleblind trials of single-dose oral celecoxib against placebo for the treatment of moderate to severe postoperative pain in adults, with at least 10 participants randomly allocated to each treatment group. We included multiple-dose studies if appropriate data from the first dose were available, and included cross-over studies provided that data from the first arm were presented separately.

We excluded studies if they were:

- posters or abstracts not followed up by full publication;

- reports of trials concerned with pain other than postoperative pain (including experimental pain);

- trials using healthy volunteers;

- trials where pain relief was assessed by clinicians, nurses or carers (i.e. not patient-reported);

- trials of less than four hours' duration or which failed to present data over four to six hours postdose.

\section{Types of participants}

We included studies of adult participants (15 years old or above) with established moderate to severe postoperative pain. For studies using a visual analogue scale (VAS), pain of at least moderate intensity was assumed when the VAS score was greater than $30 \mathrm{~mm}$ (Collins 1997). We included trials of patients with postpartum pain provided the pain investigated resulted from episiotomy or Caesarean section (with or without uterine cramp). We excluded trials investigating pain due to uterine cramps alone.

\section{Types of interventions}

Orally administered celecoxib or matched placebo for relief of postoperative pain.

\section{Types of outcome measures}

Data collected included the following if available:

- patient characteristics;

- pain model;

- patient-reported pain at baseline (physician, nurse, or carer reported pain would not be included in the analysis);

- patient-reported pain relief expressed hourly over four to six hours using validated scales, or reported total pain relief (TOTPAR) at four to six hours;
- patient-reported pain intensity expressed hourly over four to six hours using validated pain scales, or reported summed pain intensity difference (SPID) at four to six hours;

- patient-reported global evaluation of treatment using a validated scale;

- number of participants using rescue medication, and the time of assessment;

- time to use of rescue medication;

- withdrawals - all-cause, adverse event;

- adverse events - participants experiencing one or more adverse event and any serious adverse event, and the time of assessment.

\section{Primary outcomes}

Participants achieving at least $50 \%$ pain relief over four to six hours.

\section{Secondary outcomes}

1. Median (or mean) time to use of rescue medication.

2. Participants using rescue medication.

3. Participants with:

a. any adverse event;

b. any serious adverse event (as reported in the study);

c. withdrawal due to an adverse event.

4. Other withdrawals.

\section{Search methods for identification of studies}

We applied no language restriction.

\section{Electronic searches}

We searched the following electronic databases:

- the Cochrane Central Register of Controlled Trials (CENTRAL) (The Cochrane Library 2013, Issue 5 of 12);

- MEDLINE via Ovid (1966 to 31 May 2013);

- EMBASE via Ovid (1980 to 31 May 2013);

- Oxford Pain Database (Jadad 1996a);

- ClinicalTrials.gov (on 31 May 2013) for update only.

See Appendix 1 for the MEDLINE search strategy, Appendix 2 for the EMBASE search strategy, and Appendix 3 for the CENTRAL search strategy.

Searches for the original review were up to July 2008, for the first update to January 2012, and the second update to May 2013.

\section{Searching other resources}

We manually searched reference lists of retrieved studies. We did not search abstracts, conference proceedings, and other grey literature. We did not contact manufacturers. For this update we searched ClinicalTrials.gov for any unpublished and ongoing studies, and attempted to contact the study sponsors for further information. 


\section{Data collection and analysis}

\section{Selection of studies}

Two review authors independently assessed and agreed the search results for studies that might be included in the review. We resolved disagreements by consensus or referral to a third review author.

\section{Data extraction and management}

Two review authors independently extracted data and recorded it on a standard data extraction form. One author entered data suitable for pooling into RevMan 5.2 (RevMan 2012).

\section{Assessment of risk of bias in included studies}

Two review authors independently assessed each study using a three-item, five-point scale (Jadad 1996b) and agreed a consensus score.

We also completed a Risk of bias in included studies table, using methods adapted from those described by the Cochrane Pregnancy and Childbirth Group. Two authors independently assessed risk of bias for each study using the criteria outlined in the Cochrane Handbook for Systematic Reviews of Interventions (Higgins 2011), with any disagreements resolved by discussion.

The following were assessed for each study.

- Random sequence generation (checking for possible selection bias). The method used to generate the allocation sequence was assessed as: low risk of bias (any truly random process, e.g. random number table; computer random number generator); high risk of bias (any non-random process, e.g. odd or even date of birth; hospital or clinic record number) - these studies would be excluded; unclear risk of bias.

- Allocation concealment (checking for possible selection bias). The method used to conceal allocation to interventions prior to assignment assessed whether intervention allocation could have been foreseen in advance of or during recruitment, or changed after assignment. The methods were assessed as: low risk of bias (e.g. telephone or central randomisation; consecutively numbered sealed opaque envelopes); high risk of bias (open random allocation; unsealed or non-opaque envelopes, alternation; date of birth) - these studies would be excluded; unclear risk of bias.

- Blinding of outcome assessment (checking for possible detection bias). The methods used to blind study participants and outcome assessors from knowledge of which intervention a participant received were assessed. Studies were considered to be at low risk of bias if they stated that they were blinded and described the method used to achieve blinding (e.g. identical tablets; matched in appearance and smell), or at unknown risk if they stated that they were blinded but did not provide an adequate description of how it was achieved. Single-blind and open studies would be excluded.

- Size (checking for possible biases confounded by small size). Small studies have been shown to overestimate treatment effects, probably due to methodological weaknesses (Nuesch 2010). Studies were considered to be at low risk of bias if they had $\geq 200$ participants, at unknown risk of they had 50 to 200 participants, and at high risk if they had $<50$ participants.

\section{Measures of treatment effect}

We used relative risk (or 'risk ratio', RR) to establish statistical difference. We used numbers needed to treat (NNT) and pooled percentages as absolute measures of benefit or harm.

We use the following terms to describe adverse outcomes in terms of harm or prevention of harm.

- When significantly fewer adverse outcomes occur with celecoxib than with control (placebo or active) we use the term the number needed to treat to prevent one event (NNTp).

- When significantly more adverse outcomes occur with celecoxib compared with control (placebo or active) we use the term the number needed to harm or cause one event (NNH).

\section{Unit of analysis issues}

We accepted only randomisation to the individual patient.

\section{Dealing with missing data}

The only likely issue with missing data in these studies was from imputation using last observation carried forward when a patient requests rescue medication. We have previously shown that this does not affect results for up to six hours after taking study medication (Barden 2004).

\section{Assessment of heterogeneity}

We examined heterogeneity visually using L'Abbé plots (L'Abbé 1987).

\section{Data synthesis}

We followed the QUOROM guidelines (Moher 1999). For efficacy analyses we used the number of participants in each treatment group who were randomised, received medication, and provided at least one post-baseline assessment. For safety analyses we used the number of participants randomised to each treatment group who took the study medication. We planned analyses for different doses.

For each study we converted the mean TOTPAR, SPID, VAS TOTPAR, or VAS SPID (Appendix 4) values for active treatment and placebo to \%maxTOTPAR or \%maxSPID by division into the calculated maximum value (Cooper 1991), and calculated the proportion of participants in each treatment group who achieved at least 50\%maxTOTPAR using verified equations (Moore 1996; Moore 1997a; Moore 1997b). We then converted these proportions into the number of participants achieving at least $50 \%$ maxTOTPAR by multiplying by the total number of participants in the treatment group. We used this information on the number of participants with at least 50\%maxTOTPAR for active treatment and placebo to calculate relative benefit or relative risk and number needed to treat to benefit (NNT).

We accepted the following pain measures for the calculation of TOTPAR or SPID:

- five-point categorical pain relief (PR) scales with comparable wording to 'none, slight, moderate, good or complete';

- four-point categorical pain intensity (PI) scales with comparable wording to 'none, mild, moderate, severe';

- VAS for pain relief; 
- VAS for pain intensity.

If none of these measures were available, we used the number of participants reporting 'very good or excellent' on a five-point categorical global scale with the wording 'poor, fair, good, very good, excellent' for the number of participants achieving at least $50 \%$ pain relief (Collins 2001).

For each treatment group we extracted the number of participants reporting treatment-emergent adverse effects, and calculated relative benefit and risk estimates with 95\% confidence intervals (CI) using a fixed-effect model (Morris 1995). We calculated NNT and number needed to treat to harm (NNH) with 95\% Cls using the pooled number of events and the method devised by Cook and Sackett (Cook 1995). We assumed a statistically significant difference from control when the $95 \% \mathrm{Cl}$ of the relative risk or relative benefit did not include one.

\section{Subgroup analysis and investigation of heterogeneity}

We planned subgroup analyses to determine the effect of dose. A minimum of two trials and 200 participants had to be available in any subgroup or sensitivity analysis (Moore 1998), which was restricted to the primary outcome (50\% pain relief over four to six hours). We determined significant differences between NNT, NNTp, or NNH for different groups in subgroup and sensitivity analyses using the $z$ test (Tramèr 1997).

\section{Sensitivity analysis}

We planned sensitivity analyses for pain model (dental versus other postoperative pain), trial size (39 or fewer versus 40 or more per treatment arm), and quality score (two versus three or more).

\section{RES U L T S}

\section{Description of studies}

In the updated searches we found one new study for inclusion (Manvelian 2012), which had previously been identified as an unpublished study without data (DIC2-08-03). One further unpublished study had reported results (IND2-08-03). This left three potentially relevant unpublished studies that were completed:

- two in which celecoxib was used as an active comparator for an experimental compound, ARRY-371797. One (ARRY-797-222) was placebo-controlled, but the other (ARRY-797-221) may not be. We have requested further details from the study sponsor (Array BioPharma), but none were available at the time of writing;

- one in which celecoxib was compared with etodolac and placebo (177-CL-102). We were unable to contact the study sponsor.

Ten studies fulfilled the inclusion criteria, nine of which were fully published (Malmstrom 1999; Gimbel 2001; Doyle 2002; Malmstrom 2002; Kellstein 2004; Cheung 2007; Moberly 2007; Fricke 2008; Manvelian 2012) and one was available as a clinical trial summary (IND2-08-03). We identified one additional study that we excluded after reading the full paper (Saito 2012), making three excluded studies in total. One study (Shirota 2001) was in Japanese and had not yet been translated (Figure 1). Details of the included and excluded studies, and studies awaiting classification, are in the corresponding tables (Characteristics of included studies; Characteristics of excluded studies; Characteristics of studies awaiting classification).

Figure 1. Flow diagram.

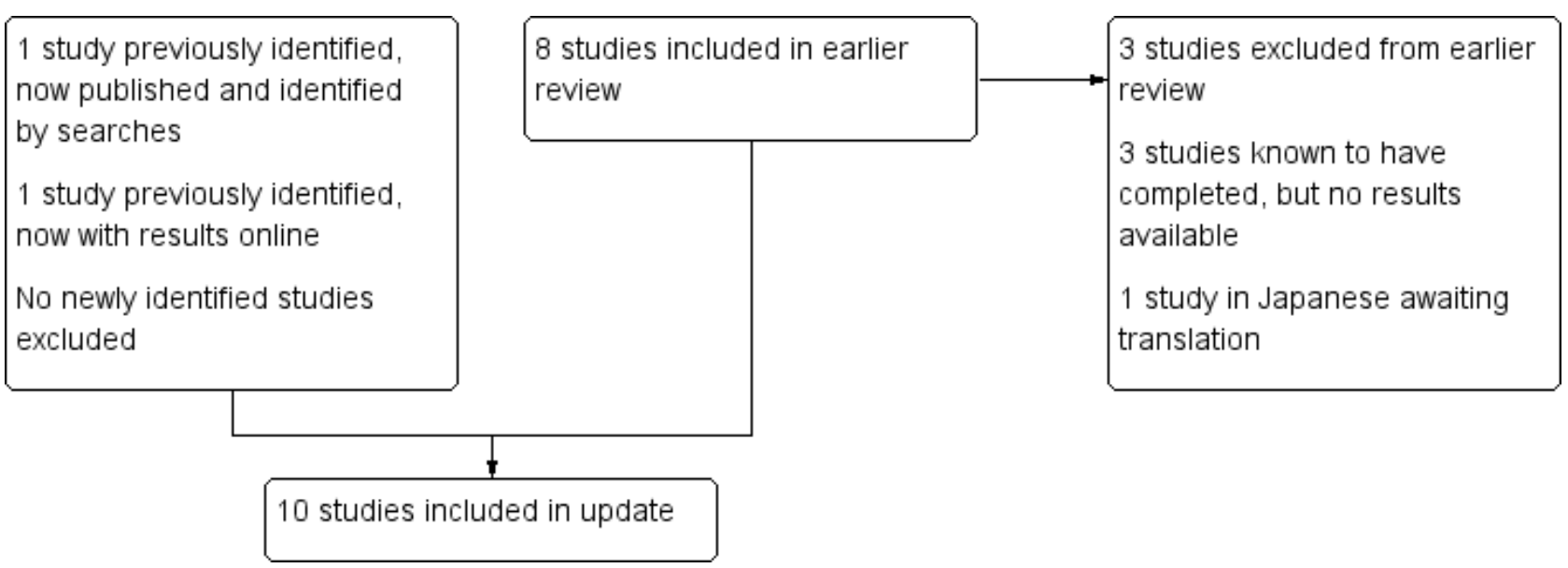

Celecoxib $200 \mathrm{mg}$ was used in five treatment arms (Malmstrom 1999; Gimbel 2001; Doyle 2002; Malmstrom 2002; Kellstein 2004), and celecoxib $400 \mathrm{mg}$ in six treatment arms (Malmstrom 2002; Cheung 2007; Moberly 2007; Fricke 2008; Manvelian 2012; IND2-08-03). In total 1785 participants were analysed; 599 received celecoxib $200 \mathrm{mg}, 415$ received celecoxib $400 \mathrm{mg}$, and 570 received placebo.

Nine studies (Malmstrom 1999; Doyle 2002; Malmstrom 2002; Kellstein 2004; Moberly 2007; Cheung 2007; Fricke 2008; IND2-08-03; Manvelian 2012) enrolled participants with dental pain following extraction of at least one impacted third molar, and one (Gimbel 2001) enrolled participants with pain following uncomplicated orthopaedic surgery. Trial duration was eight hours in three trials, 12 hours in four trials, and 24 hours in three trials. Three trials (Malmstrom 1999; Gimbel 2001; Doyle 2002) were multiple-dose studies, but provided data on the first dose for at least some outcomes.

\section{Risk of bias in included studies}

Five studies were given a quality score of five (Malmstrom 1999; Doyle 2002; Malmstrom 2002; Cheung 2007; Fricke 2008), two a 
score of four (Kellstein 2004; Moberly 2007), two studies a score of three (Gimbel 2001; IND2-08-03), and one study a score of two (Manvelian 2012). Details are in the Characteristics of included studies table.
We completed a 'Risk of bias' table and results are presented graphically in Figure 2, and summarised in Figure 3. The major threat to reliability was the relatively small size of the studies.

Figure 2. 'Risk of bias' graph: review authors' judgements about each risk of bias item presented as percentages across all included studies.

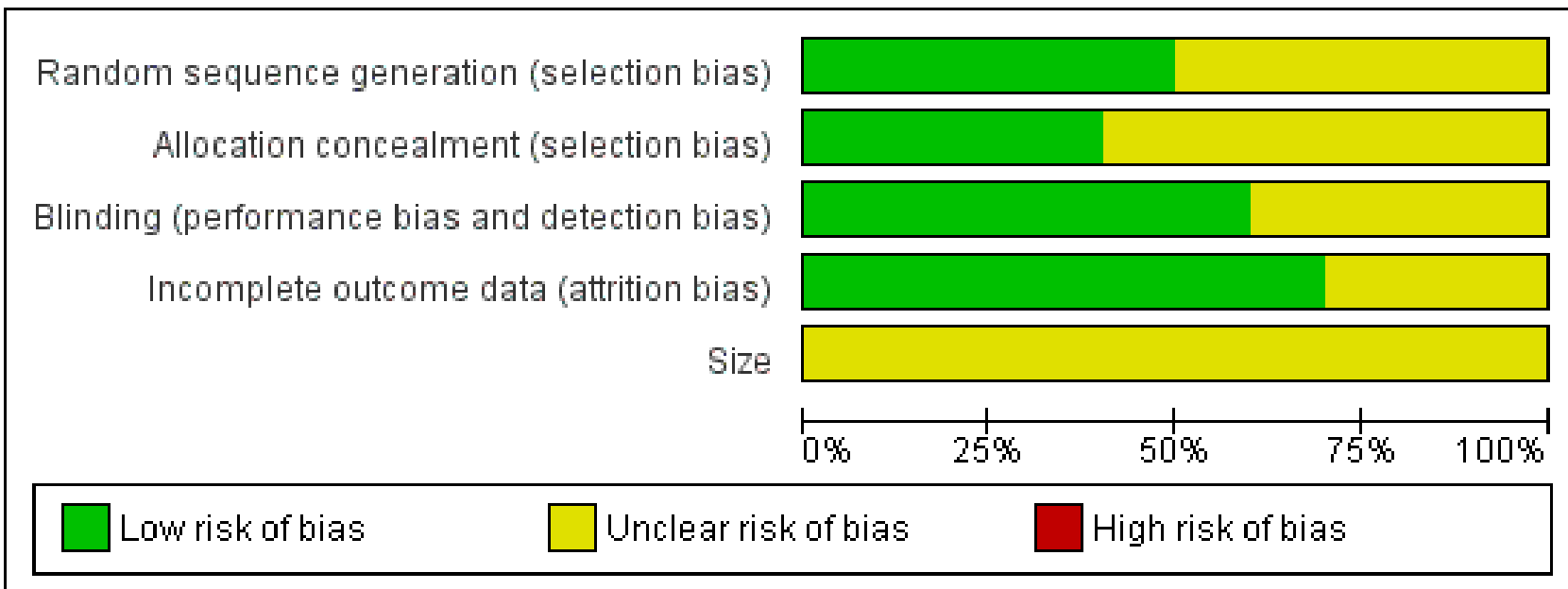


Figure 3. 'Risk of bias' summary: review authors' judgements about each risk of bias item for each included study.

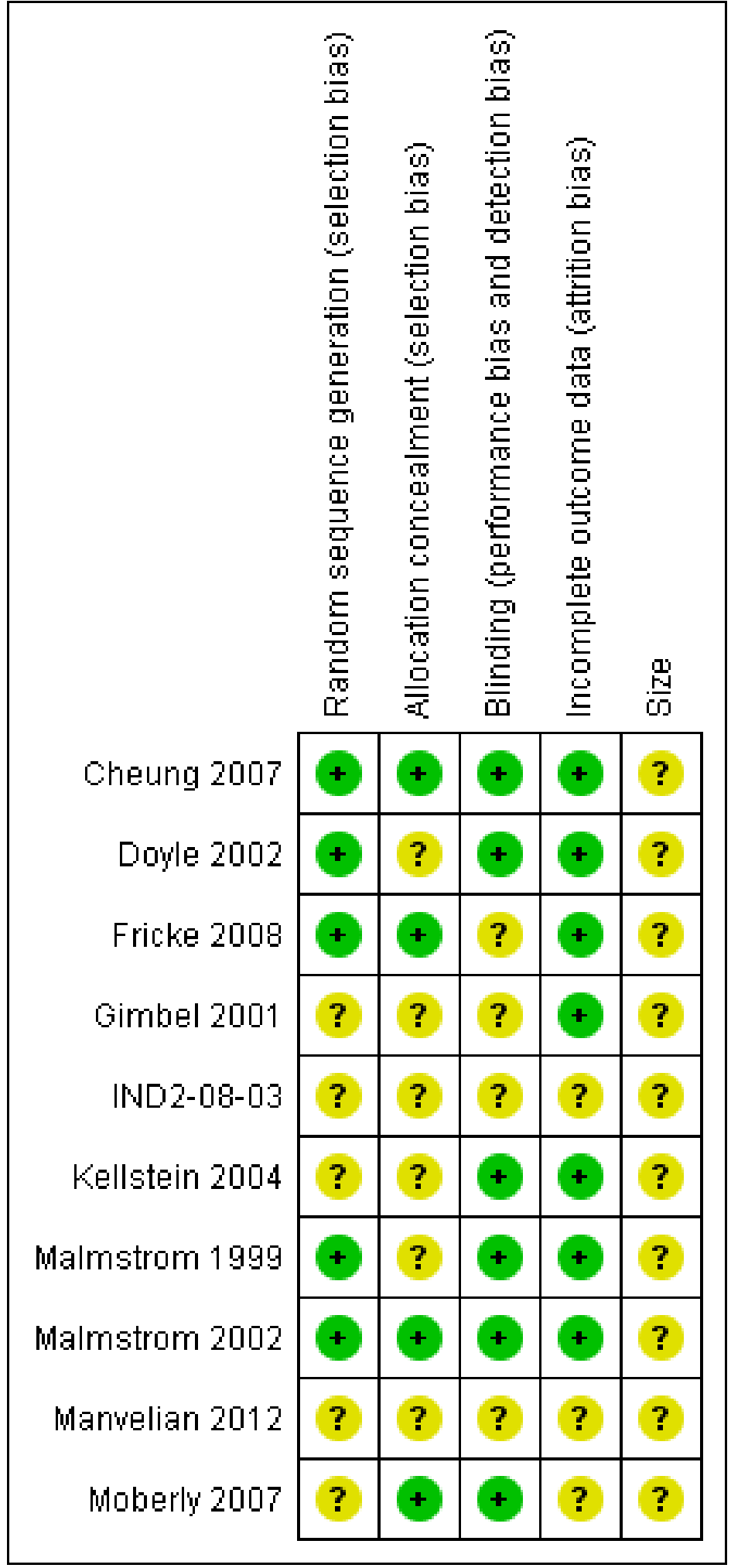

\section{Effects of interventions}

Ten studies met the inclusion criteria and provided data for analysis. Details of the results in individual studies are in Appendix 5 (efficacy) and Appendix 6 (adverse events and withdrawals). The new studies provided data for a limited number of outcomes. Manvelian 2012 reported data for the primary outcome and adverse events; IND2-08-03 reported data for pain relief in a way that we were unable to use, but it did provide information on adverse events. 


\section{Number of participants achieving at least $50 \%$ pain relief}

\section{Celecoxib 200 mg versus placebo}

- Four studies provided data (Malmstrom 1999; Gimbel 2001; Malmstrom 2002; Kellstein 2004); 423 participants were treated with celecoxib $200 \mathrm{mg}$ and 282 with placebo.
- The proportion of participants experiencing at least $50 \%$ pain relief over four to six hours with celecoxib $200 \mathrm{mg}$ was $35 \%$ (149/423).

- The proportion of participants experiencing at least $50 \%$ pain relief over four to six hours with placebo was 11\% (32/282).

- The relative benefit of treatment compared with placebo was 3.5 (95\% Cl 2.4 to 5.1); the number needed to treat to benefit (NNT) was 4.2 (95\% Cl 3.4 to 5.6) (Figure 4).

Figure 4. Forest plot of comparison: 1 Celecoxib $200 \mathrm{mg}$ versus placebo, outcome: 1.1 At least $50 \%$ pain relief over 4-6 hours.

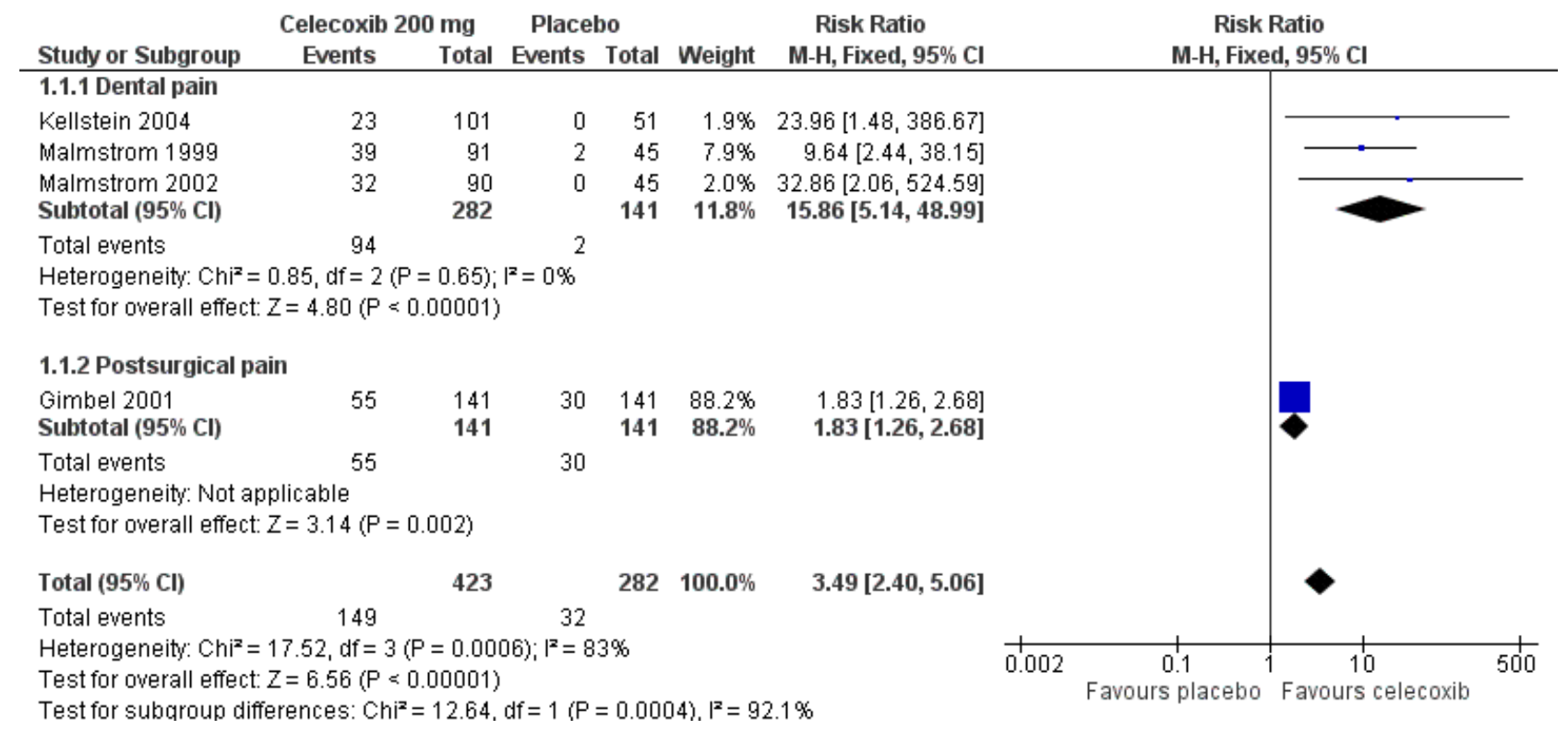

For every four participants treated with celecoxib $200 \mathrm{mg}$, one would experience at least $50 \%$ pain relief who would not have done so with placebo.
A L'Abbe plot showed a consistent response to celecoxib $200 \mathrm{mg}$ across studies, but a slightly higher response to placebo in the orthopaedic study compared to the dental studies (Figure 5). See the sensitivity analysis, below. 
Figure 5. L'Abbé plot of celecoxib $200 \mathrm{mg}$ versus placebo for at least $50 \%$ pain relief. Size of circle is proportional to size of study (inset scale). Cream circles - dental studies; pink circle - orthopaedic study.

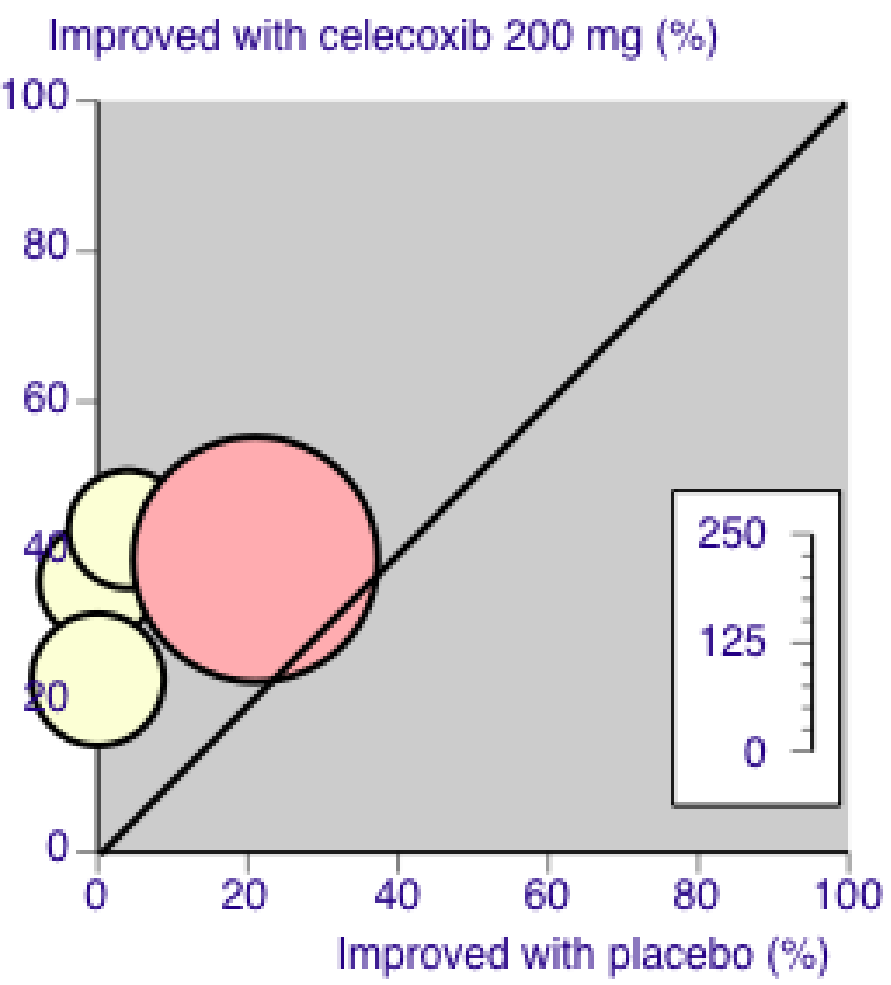

\section{Celecoxib $400 \mathrm{mg}$ versus placebo}

- Five studies provided data (Malmstrom 2002; Moberly 2007; Cheung 2007; Fricke 2008; Manvelian 2012); 466 participants were treated with celecoxib $400 \mathrm{mg}$ and 256 with placebo.

- The proportion of participants experiencing at least $50 \%$ pain relief over four to six hours with celecoxib $400 \mathrm{mg}$ was $43 \%$ (202/466).
- The proportion of participants experiencing at least $50 \%$ pain relief over four to six hours with placebo was $4.7 \%$ (12/256).

- The relative benefit of treatment compared with placebo was 10 ( $95 \% \mathrm{Cl} 5.7$ to 18 ); the NNT was $2.6(95 \% \mathrm{Cl} 2.3$ to 3.0 ) (Figure 6).

Figure 6. Forest plot of comparison: 2 Celecoxib $400 \mathrm{mg}$ versus placebo, outcome: 2.1 At least $50 \%$ pain relief over 4-6 hours dental pain.

\begin{tabular}{|c|c|c|c|c|c|c|c|c|c|c|}
\hline Study or Subgroup & \multicolumn{2}{|c|}{ Celecoxib 400 mg } & \multicolumn{2}{|c|}{ Placebo } & Weight & $\begin{array}{c}\text { Risk Ratio } \\
\text { M-H, Fixed, 95\% Cl }\end{array}$ & \multicolumn{3}{|c|}{$\begin{array}{c}\text { Risk Ratio } \\
\text { M-H, Fixed, 95\% Cl }\end{array}$} & \\
\hline Cheung 2007 & 36 & 57 & 5 & 57 & $37.0 \%$ & $7.20[3.05,17.02]$ & & & $\because-$ & \\
\hline Fricke 2008 & 49 & 156 & 0 & 52 & $5.5 \%$ & $33.42[2.10,532.45]$ & & & & \\
\hline Malmstrom 2002 & 74 & 151 & 0 & 45 & $5.7 \%$ & $45.09[2.85,713.49]$ & & & & \\
\hline Manvelian 2012 & 18 & 51 & 3 & 51 & $22.2 \%$ & $6.00[1.88,19.12]$ & & & & \\
\hline Moberly 2007 & 25 & 51 & 4 & 51 & $29.6 \%$ & $6.25[2.34,16.68]$ & & & & \\
\hline Total $(95 \% \mathrm{Cl})$ & & 466 & & 256 & $100.0 \%$ & $10.26[5.70,18.47]$ & & & & \\
\hline Total events & 202 & & 12 & & & & & & & \\
\hline $\begin{array}{l}\text { Heterogeneity: } \mathrm{Chi}^{2}= \\
\text { Test for overall effect }\end{array}$ & $\begin{array}{l}4.25, d f=4 \\
Z=7.76(P\end{array}$ & $\begin{array}{r}0.37) ; \\
00001)\end{array}$ & $P^{2}=6 \%$ & & & & $\frac{1}{0.002}$ & $\begin{array}{c}1 \\
1\end{array}$ & \begin{tabular}{|c|}
10 \\
Favours $\mathrm{ce}$
\end{tabular} & $\frac{1}{500}$ \\
\hline
\end{tabular}

For every five participants treated with celecoxib $400 \mathrm{mg}$, two would experience at least $50 \%$ pain relief who would not have done so with placebo.
A L'Abbe plot showed a consistent response to celecoxib $400 \mathrm{mg}$ across these dental pain studies (Figure 7). 
Figure 7. L'Abbé plot of celecoxib $\mathbf{4 0 0} \mathrm{mg}$ versus placebo for at least $\mathbf{5 0 \%}$ pain relief. Size of circle is proportional to size of study (inset scale). Cream circles - dental studies

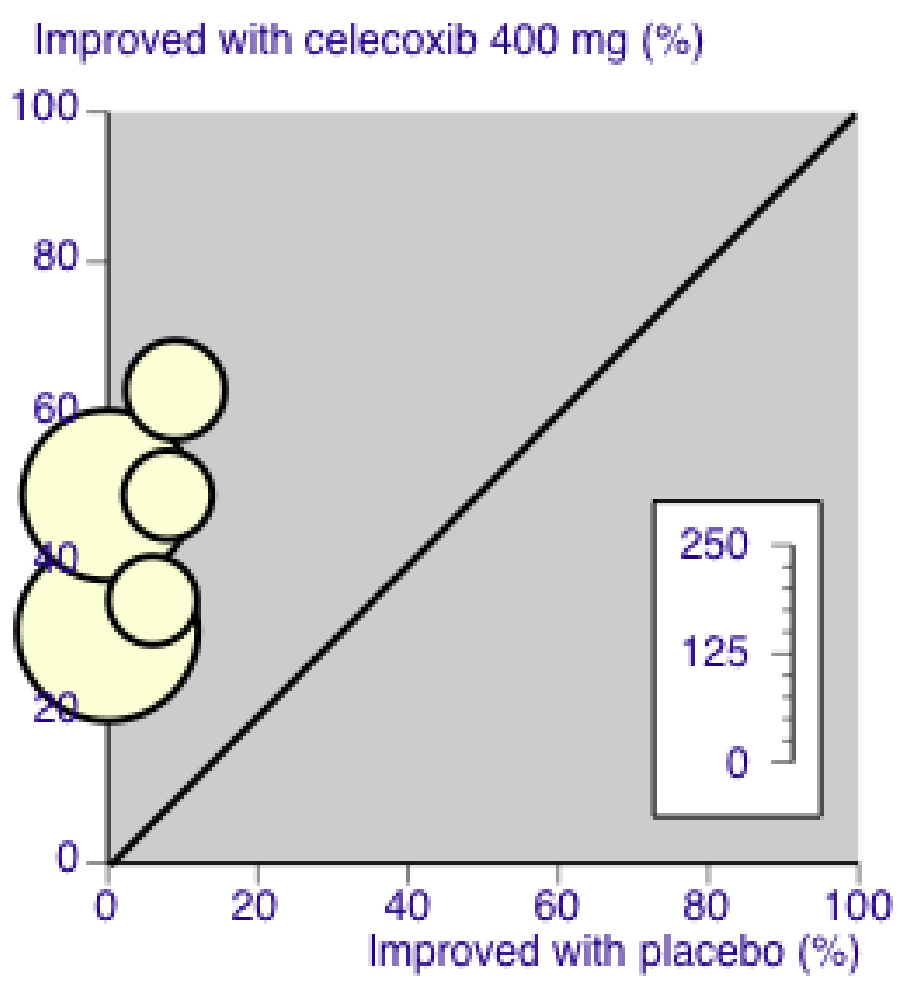

There was a significant difference between celecoxib $200 \mathrm{mg}$ and celecoxib $400 \mathrm{mg}(\mathrm{z}=3.71, \mathrm{P}=0.0002)$. 


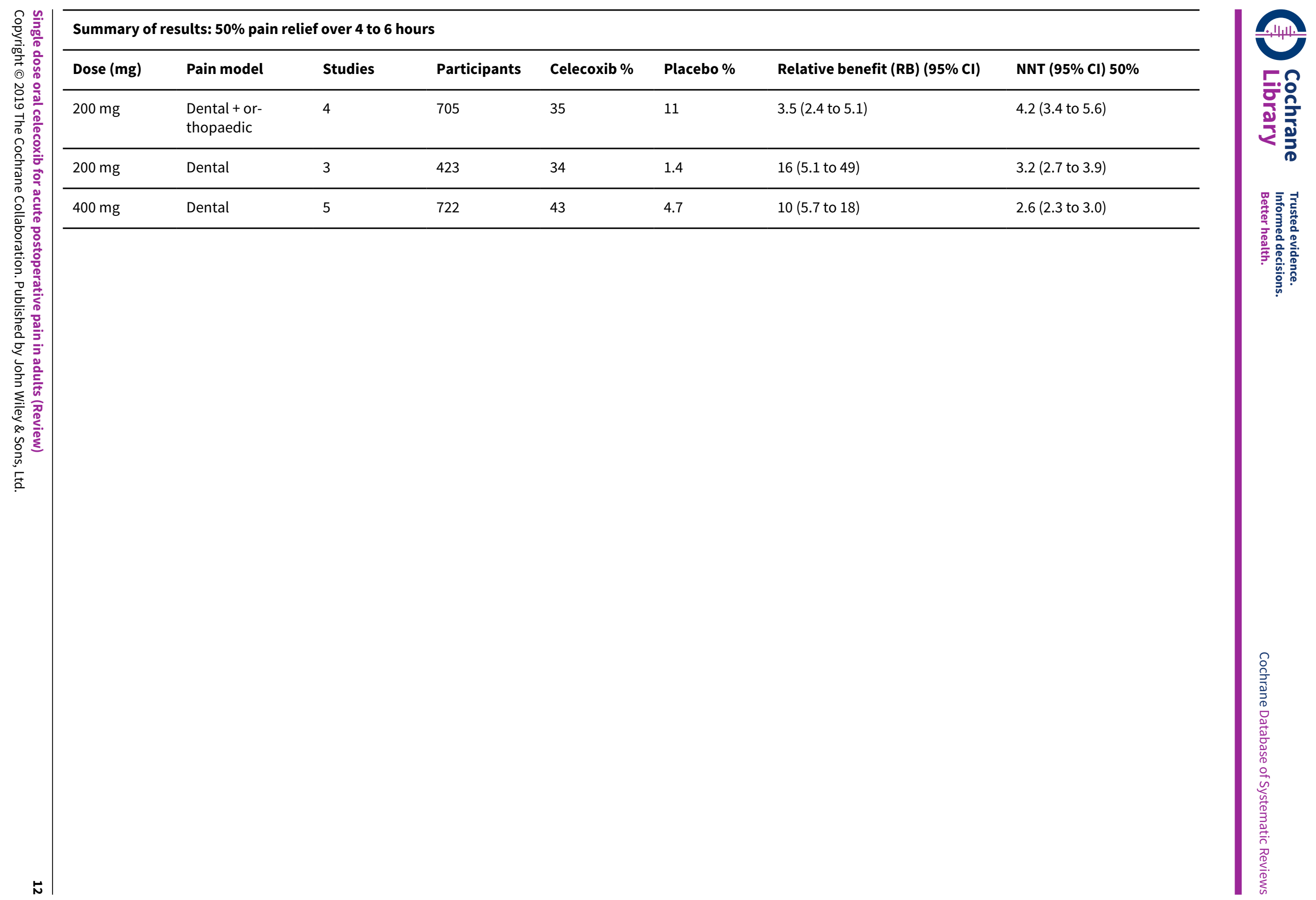




\section{Use of rescue medication}

Eight studies reported some information on use of rescue medication.

\section{Number of participants using rescue medication over 24 hours}

The time at which use of rescue medication was censored varied between studies. The weighted mean proportion of participants requiring rescue medication by 24 hours was $74 \%$ for celecoxib $200 \mathrm{mg}$ (133/181), 63\% for celecoxib $400 \mathrm{mg}$ (228/364), and 91\% for placebo (181/199 participants). Significantly fewer participants used rescue medication with celecoxib than placebo $(200 \mathrm{mg}$ : relative risk (RR) $0.8(95 \% \mathrm{Cl} 0.7$ to 0.9$)$, NNT to prevent use of rescue medication 4.8 ( $95 \% \mathrm{Cl} 3.5$ to 7.7$)$; $400 \mathrm{mg}$ : RB 0.7 (95\% Cl 0.6 to 0.8 ), NNT to prevent use of rescue medication $3.5(95 \% \mathrm{Cl} 2.9$ to 4.6$))$. The difference between the two doses of celecoxib was not significant $(z=1.37, P=0.085)$.

The proportion of participants requiring rescue medication was also reported at eight hours: 44\% (Gimbel 2001) and 12 hours: $41 \%$ (Doyle 2002) for celecoxib $200 \mathrm{mg}$; and at six hours: 24\% (Moberly 2007) for celecoxib $400 \mathrm{mg}$. 


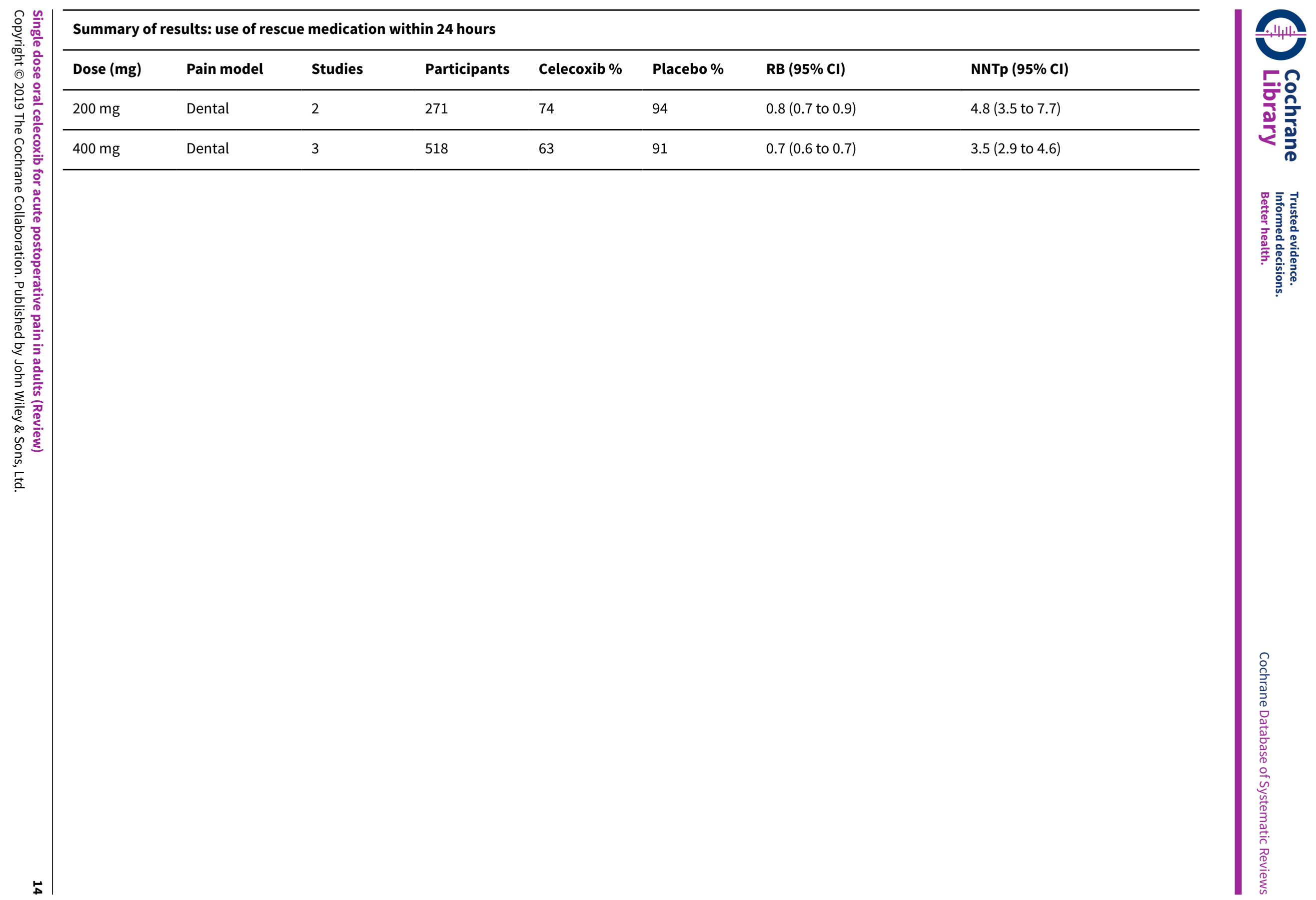




\section{Time to use of rescue medication}

The median time to use of rescue medication was highly variable, particularly for the celecoxib treatment arms. It ranged from two to $>12$ hours for celecoxib $200 \mathrm{mg}, 3.8$ to $>12$ hours for celecoxib $400 \mathrm{mg}$, and 1.3 to 3.9 hours for placebo. The weighted mean of the median time to use of rescue medication was 6.6 hours for celecoxib $200 \mathrm{mg}, 8.4$ hours for celecoxib $400 \mathrm{mg}$, and 2.3 hours for placebo ( 2.6 hours in $200 \mathrm{mg}$ trials and 1.6 hours in $400 \mathrm{mg}$ trials). For dental studies only the weighted mean of the median time to use of rescue medication was 6.1 hours for celecoxib $200 \mathrm{mg}$, and 1.5 hours for placebo.

Summary of results: weighted mean of median time to use of rescue medication

\begin{tabular}{llllll}
\hline Dose $(\mathbf{m g})$ & Pain model & Studies & Participants & Celecoxib (hr) & Placebo (hr) \\
\hline $200 \mathrm{mg}$ & Dental + orthopaedic & 5 & 805 & 6.6 & 2.6 \\
\hline $200 \mathrm{mg}$ & Dental & 4 & 523 & 6.1 & 1.5 \\
\hline $400 \mathrm{mg}$ & Dental & 4 & 620 & 8.4 & 1.6 \\
\hline
\end{tabular}

\section{Adverse events}

All studies except Malmstrom 1999 reported the number of participants with one or more adverse events for each treatment arm, although the time over which the information was collected varied between trials, from eight to 24 hours (Appendix 6). It was unclear in some reports whether the adverse event reports covered only the duration of the trial, or whether they included any adverse events occurring between the end of the trial and a follow-up visit some days later. Only one study arm reported a significant difference between placebo and celecoxib (400 mg) (Malmstrom 2002). There was no significant difference between celecoxib 400 $\mathrm{mg}$ and placebo when studies were pooled (Analysis 2.3), or for individual or pooled studies for celecoxib $200 \mathrm{mg}$ (Analysis 1.3), so we did not calculate numbers needed to treat to harm (NNHs). Adverse events were generally described as mild to moderate in severity. 


\begin{tabular}{|c|c|c|c|c|c|c|c|}
\hline \multicolumn{8}{|c|}{ Summary of results: participants with at least one adverse event } \\
\hline Dose (mg) & Pain model & Studies & Participants & Celecoxib \% & Placebo \% & $\mathbf{R R}(95 \% \mathrm{CI})$ & NNH $(95 \% \mathrm{Cl})$ \\
\hline $200 \mathrm{mg}$ & Dental + orthopaedic & 4 & 669 & 16 & 17 & $0.90(0.63$ to 1.3$)$ & Not calculated \\
\hline $200 \mathrm{mg}$ & Dental & 3 & 382 & 20 & 18 & $0.97(0.63$ to 1.5$)$ & Not calculated \\
\hline $400 \mathrm{mg}$ & Dental & 6 & 725 & 38 & 46 & $1.0(0.84$ to 1.2$)$ & $12[6.3,78]$ \\
\hline
\end{tabular}


Two studies reported serious adverse events. Malmstrom 2002 reported one serious adverse event in each of the $200 \mathrm{mg}$ and 400 $\mathrm{mg}$ treatment arms. These events were reported at the post-study visit and were judged unrelated to the study medication. Cheung 2007 reported one serious adverse event in a participant treated with celecoxib $400 \mathrm{mg}$. The event, rhabdomyolysis, occurred two days after the study and was judged to be probably related to the study medication by the trialists, although the patient had received a number of other medications both pre and post-study. No statistical analysis of serious adverse events was possible.

One adverse event withdrawal was reported for celecoxib $200 \mathrm{mg}$ (Malmstrom 1999) and for celecoxib $400 \mathrm{mg}$ (Cheung 2007), and four for placebo (Malmstrom 1999; Cheung 2007).

\section{Other withdrawals}

Withdrawals for reasons other than lack of efficacy (participants who used rescue medication) were uncommon and usually due to protocol violations (Appendix 6). No further statistical analysis of withdrawals was possible.

\section{Sensitivity analyses}

\section{Pain model}

One trial using celecoxib $200 \mathrm{mg}$ (Gimbel 2001) included participants who had undergone orthopaedic surgery. Excluding this trial from the primary analysis left dental trials only, giving an RB for treatment compared with placebo of 16 (95\% Cl 5.1 to 49), and a NNT for at least $50 \%$ pain relief over four to six hours of 3.2 $(95 \% \mathrm{Cl} 2.7$ to 3.9$)$. This apparently better efficacy in dental trials was due to the fact that the event rate in the placebo group of the orthopaedic trial was much higher $(21 \%)$ than in the placebo groups of the dental trials ( $1 \%$ to $4 \%$ ), while the event rate in the celecoxib group of the orthopaedic trial was more similar (39\%) to the dental trials (23\% to $43 \%$ ). It was not possible to draw any firm conclusions about the effect of pain model with only one nondental trial in this data set.

\section{Quality score}

Only one study scored $2 / 5$, so we did not carry out a sensitivity analysis. Removing this study from the analysis did not change the result.

\section{Trial size}

All studies enrolled more than 40 participants per treatment arm, so we did not carry out a sensitivity analysis.

\section{DISCUSSION}

\section{Summary of main results}

Data from two new studies were available for this updated review, although only one study contributed to the primary outcome. Included studies involved 1785 participants of whom 599 received celecoxib $200 \mathrm{mg}, 415$ received celecoxib $400 \mathrm{mg}$, and 570 received placebo. The number needed to treat to benefit (NNT) for at least $50 \%$ pain relief over four to six hours was significantly better for 400 $\mathrm{mg}$ (NNT 2.6, 95\% Cl 2.3 to 3.0) than for $200 \mathrm{mg}$ (NNT 4.2, 95\% Cl 3.4 to 5.6) $(\mathrm{P}=0.0002)$. The additional data did not significantly change the result.
Since the same methods and analyses have been conducted, it is possible to compare the NNT for a single dose of oral celecoxib with that of a single dose of other NSAIDs. Analgesics with comparable efficacy to celecoxib $200 \mathrm{mg}$ include aspirin 600 to $650 \mathrm{mg}$ (NNT 4.2, $95 \% \mathrm{Cl} 3.8$ to 4.6 ) (Derry 2012) and paracetamol $1000 \mathrm{mg}$ (NNT 3.6, $95 \% \mathrm{Cl} 3.2$ to 4.1 ) (Toms 2008). Analgesics with comparable efficacy to celecoxib $400 \mathrm{mg}$ include naproxen 500 to $550 \mathrm{mg}$ (NNT 2.7, 95\% $\mathrm{Cl} 2.3$ to 3.3) (Derry C 2009a) and ibuprofen $400 \mathrm{mg}$ (NNT 2.5, 95\% $\mathrm{Cl} 2.4$ to 2.6) (Derry C 2009b). An overview of analgesic efficacy in acute pain summarises all the available results (Moore 2011a).

Significantly fewer participants required rescue medication with celecoxib than with placebo. The NNTs to prevent one patient remedicating within 24 hours were 4.8 for celecoxib $200 \mathrm{mg}$ and 3.5 for celecoxib $400 \mathrm{mg}$, but the difference was not significant $(\mathrm{P}=$ 0.085 ). The median time to use of rescue medication varied greatly between trials, particularly for the active treatment arms, but was generally longer for celecoxib than placebo, and for celecoxib 400 $\mathrm{mg}$ than celecoxib $200 \mathrm{mg}$. The weighted mean of the median time to use of rescue medication at 6.6 hours for celecoxib $200 \mathrm{mg}$ and 8.4 hours for celecoxib $400 \mathrm{mg}$ is longer than for some non-selective NSAIDs (ibuprofen $400 \mathrm{mg} 5.6$ hours, diclofenac $50 \mathrm{mg} 4.3$ hours), though not all (naproxen $500 \mathrm{mg} 8.9$ hours), but is shorter than other coxibs (etoricoxib $120 \mathrm{mg} 20$ hours, rofecoxib $50 \mathrm{mg} 14$ hours, lumiracoxib nine hours). A longer duration of action is desirable in an analgesic, particularly in a postoperative setting where the patient may experience postoperative nausea or be dependent on a third party to respond to a request for rescue medication (or both).

Assessment of adverse events is limited in single-dose studies as the size and duration of the trials permit only the simplest analysis, as has been emphasised previously (Edwards 1999b). There were insufficient data in these studies to compare individual adverse events. There was no significant difference between celecoxib and placebo for numbers of participants experiencing any adverse event in the hours immediately following a single dose of the study medication. Although all but one trial reported this outcome, combining results was potentially hampered by the different periods over which the data were collected. Most adverse events were reported as mild to moderate in intensity, and were most likely to be related to the anaesthetic or surgical procedure (for example nausea, vomiting, and somnolence). Serious adverse events and withdrawals due to adverse events occurred in both celecoxib and placebo treatment arms, but were uncommon and too few for any statistical analysis. It is important to recognise that adverse event analysis after single-dose oral administration will not reflect possible adverse events occurring with use of drugs for longer periods of time. In addition, the numbers of participants are insufficient to detect rare but serious adverse events.

\section{Overall completeness and applicability of evidence}

The included studies reported useful data for both the primary and secondary outcomes with the exception of Doyle 2002 and IND2-08-03 for the primary outcome. Nine studies enrolled participants with dental pain following extraction of at least one impacted third molar. These individuals are generally in their early 20 s and are otherwise fit and healthy, so are clearly not representative of the range of individuals who might need analgesia for acute postoperative pain. There is no a priori reason why the analgesic response in these individuals should differ in any systematic way from a more generalised population, but it is entirely possible that adverse events (gastrointestinal in particular) 
may be more frequent, intense, or severe in older patients and those with comorbidities. The remaining study (Gimbel 2001) was carried out in patients with pain following uncomplicated orthopaedic surgery. The placebo response in this study was unusually high $(21 \%)$, which gave reduced efficacy. It is impossible to speculate whether there is a real difference between pain conditions where there is only one study to consider. Differences between different pain models have either not been demonstrable in the past (Barden 2004), or have been possible to demonstrate only where there are an abundance of data (for example for ibuprofen) (Derry C 2009b).

There were no data available for lower doses of celecoxib, so conclusions and inferences about the benefit and harm of a lower dose cannot be made.

The lack of availability of three completed randomised trials means that not all of the extant information on celecoxib in acute pain was available for analysis.

\section{Quality of the evidence}

All studies were of adequate methodological quality, with five scoring 5/5 on the Oxford Quality Scale. Points were lost mainly due to failure to adequately report details of the methods used for randomisation and blinding, and may well result from inadequate reporting rather than inadequate study conduct. The risk of bias assessment indicated that modest group sizes may contribute an unknown level of bias.

All studies administered the medication when pain levels were moderate or severe, ensuring that the study was sensitive to detect a $50 \%$ reduction.

\section{Potential biases in the review process}

We carried out a comprehensive search for relevant studies, and investigated the potential influence of publication bias by examining the number of participants in trials with zero effect (relative risk of 1.0) needed for the point estimate of the NNT to increase beyond a clinically useful level (Moore 2008). In this case, we chose a clinically useful level as 8 . For the primary outcome of at least 50\% pain relief with celecoxib $200 \mathrm{mg}$, about 640 participants would have to have been involved in unpublished trials with zero treatment effects for the NNT to increase above this threshold. For celecoxib $400 \mathrm{mg}$, more than twice as many (1500) participants in unpublished trials would be needed. Given that we know of three unpublished but completed studies, one study in Japanese awaiting translation, and two of the included studies did not provide data for the primary outcome, it is possible, although unlikely, that these results could be overturned, although efficacy estimates could be changed.

\section{Agreements and disagreements with other studies or reviews}

We are not aware of any other systematic reviews of celecoxib in treating acute postoperative pain.

\section{AUTHORS' CONCLUSIONS}

\section{Implications for practice}

A small amount of additional data were identified for this update but the conclusions of the previous review are unchanged. Celecoxib at its recommended dosage of $400 \mathrm{mg}$ for acute pain is an effective analgesic, equivalent to ibuprofen $400 \mathrm{mg}$, but providing a longer duration of pain relief than many traditional NSAIDs. Significantly fewer individuals achieve effective pain relief with celecoxib $200 \mathrm{mg}$ than with celecoxib $400 \mathrm{mg}$.

\section{Implications for research}

There are no major implications for research other than the possible benefits that are known to come from single-patient analysis, allowing different ways of reporting trial results, which can be more useful to clinical practices (Edwards 1999a).

\section{ACKNOWLEDGEMENTS}

Tom Weir (work experience student) helped with all aspects of this update.

This update was supported by funds from the Oxford Pain Relief Trust. Earlier updates were supported by the NHS Cochrane Collaboration Programme Grant Scheme.

Jodie Barden, Jane Edwards, and Henry McQuay were involved in the earlier reviews. 


\section{REFERE N CES}

\section{References to studies included in this review}

\section{Cheung 2007 \{published data only\}}

Cheung R, Krishnaswami S, Kowalski K. Analgesic efficacy of celecoxib in postoperative oral surgery pain: a single-dose, two-center, randomized, double-blind, active- and placebocontrolled study. Clinical Therapeutics 2007;29 Suppl:2498-510.

Doyle 2002 \{published data only\}

Doyle G, Jayawardena S, Ashraf E, Cooper SA. Efficacy and tolerability of nonprescription ibuprofen versus celecoxib for dental pain. Journal of Clinical Pharmacology 2002;42(8):912-9.

\section{Fricke 2008 \{published data only\}}

Fricke J, Davis N, Yu V, Krammer G. Lumiracoxib 400 mg compared with celecoxib $400 \mathrm{mg}$ and placebo for treating pain following dental surgery: a randomized, controlled trial. The Journal of Pain 2008;9(1):20-7.

\section{Gimbel 2001 \{published data only\}}

Gimbel JS, Brugger A, Zhao W, Verburg KM, Geis GS. Efficacy and tolerability of celecoxib versus hydrocodone/acetaminophen in the treatment of pain after ambulatory orthopedic surgery in adults. Clinical Therapeutics 2001;23(2):228-41.

\section{IND2-08-03 \{unpublished data only\}}

A phase 2, randomized, double-blind, single-dose, parallelgroup, active- and placebo-controlled study of indomethacin test capsules for the treatment of pain after surgical removal of impacted third molars. http://www.clinicaltrials.gov/ 2013 (Accessed 31 May 2013). [CTG: NCT00964431]

\section{Kellstein 2004 \{published data only\}}

Kellstein D, Ott D, Jayawardene S, Fricke J. Analgesic efficacy of a single dose of lumiracoxib compared with rofecoxib, celecoxib and placebo in the treatment of post-operative dental pain. International Journal of Clinical Practice 2004;58(3):244-50.

\section{Malmstrom 1999 \{published data only\}}

Malmstrom K, Daniels S, Kotey P, Seidenburg BC, Desjardins PJ. Comparison of rofecoxib and celecoxib, two cyclooxygenase-2 inhibitors, in postoperative dental pain: a randomised, placeboand active-comparator-controlled clinical trial. Clinical Therapeutics 1999;21(10):1653-63.

\section{Malmstrom 2002 \{published data only\}}

Malmstrom K, Fricke JR, Kotey P, Kress B, Morrison B. A comparison of rofecoxib versus celecoxib in treating pain after dental surgery: a single-center, randomized, double-blind, placebo- and active-comparator-controlled, parallel-group, single-dose study using the dental impaction pain model. Clinical Therapeutics 2002;24(10):1549-60.

\section{Manvelian 2012 \{published data only\}}

Manvelian G, Daniels S, Gibofsky A. A phase 2 study evaluating the efficacy and safety of a novel, proprietary, nano-formulated, lower dose oral diclofenac. Pain Medicine 2012;13(11):1491-8. [DOI: 10.1111/j.1526-4637.2012.01479.x]
Moberly 2007 \{published data only\}

Moberly JB, Xu J, Desjardins PJ, Daniels SE, Bandy DP, Lawson JE, et al. A randomized, double-blind, celecoxiband placebo-controlled study of the effectiveness of CS-706 in acute postoperative dental pain. Clinical Therapeutics 2007;29(3):399-412.

\section{References to studies excluded from this review}

\section{Saito 2012 \{published data only\}}

Saito K, Kaneko A, Machii K, Ohta H, Ohkura M, Suzuki M. Efficacy and safety of additional 200-mg dose of celecoxib in adult patients with postoperative pain following extraction of impacted third mandibular molar: a multicenter, randomized, double-blind, placebo-controlled, phase II study in Japan. Clinical Therapeutics 2012;34(2):314-28. [DOI: 10.1016/ j.clinthera.2012.01.004]

\section{Salo 2003 \{published data only\}}

Salo DF, Lavery R, Varma V, Goldberg J, Shapiro T, Kenwood A. A randomized, clinical trial comparing oral celecoxib 200 $\mathrm{mg}$, celecoxib $400 \mathrm{mg}$, and ibuprofen $600 \mathrm{mg}$ for acute pain. Academic Emergency Medicine 2003;10:22-30.

\section{White 2007 \{published data only\}}

White PF, Sacan O, Tufanogullari B, Eng M, Nuangchamnong N, Ogunnaike B. Effect of short-term postoperative celecoxib administration on patient outcome after outpatient laparoscopic surgery. Canadian Journal of Anaesthesia 2007;54(5):342-8.

\section{References to studies awaiting assessment}

177-CL-102 \{unpublished data only\}

An etodolac- and placebo-controlled, multicenter, doubleblind, group comparison study to verify the efficacy of YM177 (celecoxib) in postoperative pain patients. [CTG: NCT01118572]

\section{ARRY-797-221 \{unpublished data only\}}

\section{ARRY-797-222 \{unpublished data only\}}

A randomized, double-blind, placebo- and active-controlled, parallel-group analgesic efficacy trial of oral ARRY-371797 in subjects undergoing third molar extraction. [CTG: NCT00663767]

\section{Shirota 2001 \{published data only\}}

Shirota T, Ohno K-S, Michii K-I, Kamijo R, Nagumo M, Sato H, et al. A study of the dose-response of YM177 for treatment of postsurgical dental pain. Oral Therapeutics and Pharmacology 2001;20(3):154-72. 


\section{Additional references}

\section{Barden 2004}

Barden J, Edwards JE, McQuay HJ, Andrew Moore R. Pain and analgesic response after third molar extraction and other postsurgical pain. Pain 2004;107(1-2):86-90. [DOI: 10.1016/ j.pain.2003.09.021]

\section{Clarke 2012}

Clarke R, Derry S, Moore RA. Single dose oral etoricoxib for acute postoperative pain in adults. Cochrane Database of Systematic Reviews 2012, Issue 4. [DOI: 10.1002/14651858.CD004309.pub3]

\section{Collins 1997}

Collins SL, Moore RA, McQuay HJ. The visual analogue pain intensity scale: what is moderate pain in millimetres?. Pain 1997;72:95-7.

\section{Collins 2001}

Collins SL, Edwards J, Moore RA, Smith LA, McQuay HJ. Seeking a simple measure of analgesia for mega-trials: is a single global assessment good enough?. Pain 2001;91:189-94.

\section{Cook 1995}

Cook RJ, Sackett DL. The number needed to treat: a clinically useful measure of treatment effect. BMJ 1995;310:452-4.

\section{Cooper 1991}

Cooper SA. Single-dose analgesic studies: the upside and downside of assay sensitivity. In: Max MB, Portenoy RK, Laska EM editor(s). The Design of Analgesic ClinicalTrials. Advances in Pain Research and Therapy. Vol. 18, New York: Raven Press, 1991:117-24.

\section{Derry 2011}

Derry S, Wiffen PJ, Moore RA. Relative efficacy of oral analgesics after third molar extraction - a 2011 update. British Dental Journal 2011;211(9):419-20. [DOI: 10.1038/sj.bdj.2011.905]

\section{Derry 2012}

Derry S, Moore RA. Single dose oral aspirin for acute postoperative pain in adults. Cochrane Database of Systematic Reviews 2012, Issue 4. [DOI: 10.1002/14651858.CD002067.pub2]

\section{Derry C 2009a}

Derry C, Derry S, Moore RA, McQuay HJ. Single dose oral naproxen and naproxen sodium for acute postoperative pain in adults. Cochrane Database of Systematic Reviews 2009, Issue 1. [DOI: 10.1002/14651858.CD004234.pub2]

\section{Derry C 2009b}

Derry C, Derry S, Moore RA, McQuay HJ. Single dose oral ibuprofen for acute postoperative pain in adults. Cochrane Database of Systematic Reviews 2009, Issue 3. [DOI: 10.1002/14651858.CD001548.pub2]

\section{Derry P 2009}

Derry P, Derry S, Moore RA, McQuay HJ. Single dose oral diclofenac for acute postoperative pain in adults. Cochrane Database of Systematic Reviews 2009, Issue 2. [DOI: 10.1002/14651858.CD004768.pub2]

\section{Edwards 1999a}

Edwards JE, Oldman AD, Smith LA, Carroll D, Wiffen PJ, McQuay HJ, et al. Oral aspirin in postoperative pain: a quantitative systematic review. Pain 1999;81:289-97.

\section{Edwards 1999b}

Edwards JE, McQuay HJ, Moore RA, Collins SL. Reporting of adverse effects in clinical trials should be improved: lessons from acute postoperative pain. Journal of Pain and Symptom Management 1999;18(6):427-37.

\section{Garner 2002}

Garner S, Fidan D, Frankish R, Judd M, Towheed T, Wells G, et al. Rofecoxib for the treatment of rheumatoid arthritis. Cochrane Database of Systematic Reviews 2002, Issue 2. [DOI: 10.1002/14651858.CD003685.pub2]

\section{Grahame-Smith 2002}

Grahame-Smith DG, Aronson JK. Oxford Textbook of Clinical Pharmacology and Drug Therapy. 3rd Edition. Oxford: Oxford University Press, 2002.

\section{Hawkey 1999}

Hawkey CJ. Cox-2 inhibitors. Lancet 1999;353(9149):307-14.

\section{Hawkey 2001}

Hawkey, CJ. Gastrointestinal safety of COX-2 specific inhibitors. Gastroenterology Clinics of North America 2001;30(4):921-36.

\section{Higgins 2011}

Altman DG, Antes G, Gøtzsche P, Higgins JPT, Jüni P, Lewis S, et al. Assessing risk of bias in included studies. In: Higgins JPT, Altman DG, Sterne JAC editor(s). Cochrane Handbook for Systematic Reviews of Interventions. Version 5.1.0 [updated March 2011]. www.cochrane-handbook.org. The Cochrane Collaboration, 2011.

\section{Jadad 1996a}

Jadad A, Carroll D, Moore RA, McQuay HJ. Developing a database of published reports of randomised clinical trials in pain research. Pain 1996;66:239-46.

\section{Jadad 1996b}

Jadad AR, Moore RA, Carroll D, Jenkinson C, Reynolds DJM, Gavaghan DJ, et al. Assessing the quality of reports of randomized clinical trials: is blinding necessary?. Controlled Clinical Trials 1996;17:1-12.

\section{L'Abbé 1987}

L'Abbé KA, Detsky AS, O'Rourke K. Meta-analysis in clinical research. Annals of Internal Medicine 1987;107:224-33.

\section{McQuay 2005}

McQuay HJ, Moore RA. Placebo. Postgraduate Medical Journal 2005;81:155-60.

\section{Moher 1999}

Moher D, Cook DJ, Eastwood S, Olkin I, Rennie D, Stroup DF. Improving the quality of reports of meta-analyses of randomised controlled trials: the QUOROM statement. Quality of Reporting of Meta-analyses. Lancet 1999;27(354):1896-900. 


\section{Moore 1996}

Moore A, McQuay H, Gavaghan D. Deriving dichotomous outcome measures from continuous data in randomised controlled trials of analgesics. Pain 1996;66(2-3):229-37.

\section{Moore 1997a}

Moore A, McQuay H, Gavaghan D. Deriving dichotomous outcome measures from continuous data in randomised controlled trials of analgesics: verification from independent data. Pain 1997;69(1-2):127-30.

\section{Moore 1997b}

Moore A, Moore O, McQuay H, Gavaghan D. Deriving dichotomous outcome measures from continuous data in randomised controlled trials of analgesics: use of pain intensity and visual analogue scales. Pain 1997;69(3):311-5.

\section{Moore 1998}

Moore RA, Gavaghan D, Tramer M, Collins SL, McQuay HJ. Size is everything - large amounts of information are needed to overcome random effects in estimating direction and magnitude of treatment effects. Pain 1998;78(3):209-16.

\section{Moore 2003}

Moore RA, Edwards J, Barden J, McQuay HJ. Bandolier's Little Book of Pain. Oxford: Oxford University Press, 2003.

\section{Moore 2005a}

Moore RA, Edwards JE, McQuay HJ. Acute pain: individual patient meta-analysis shows the impact of different ways of analysing and presenting results. Pain 2005;116(3):322-31.

\section{Moore 2005b}

Moore RA, Derry S, Makinson GT, McQuay HJ. Tolerability and adverse events in clinical trials of celecoxib in osteoarthritis and rheumatoid arthritis: systematic review and meta-analysis of information from company clinical trial reports. Arthritis Research and Therapy 2005;7(3):R644-65.

\section{Moore 2006}

Moore A, McQuay H. Bandolier's Little Book of Making Sense of the Medical Evidence. Oxford: Oxford University Press, 2006.

\section{Moore 2008}

Moore RA, Barden J, Derry S, McQuay HJ. Managing potential publication bias. In: McQuay HJ, Kalso E, Moore RA editor(s). Systematic Reviews in Pain Research: Methodology Refined. Seattle: IASP Press, 2008:15-24. [ISBN: 978-0-931092-69-5]

\section{Moore 2011a}

Moore RA, Derry S, McQuay HJ, Wiffen PJ. Single dose oral analgesics for acute postoperative pain in adults. Cochrane Database of Systematic Reviews 2011, Issue 9. [DOI: 10.1002/14651858.CD008659.pub2]

\section{Moore 2011b}

Moore RA, Straube S, Paine J, Derry S, McQuay HJ. Minimum efficacy criteria for comparisons between treatments using individual patient meta-analysis of acute pain trials: examples of etoricoxib, paracetamol, ibuprofen, and ibuprofen/ paracetamol combinations after third molar extraction. Pain 2011;152(5):982-9. [DOI: doi:10.1016/j.pain.2010.11.030]

\section{Morris 1995}

Morris JA, Gardner MJ. Calculating confidence intervals for relative risk, odds ratio and standardised ratios and rates. In: Gardner MJ, Altman DG editor(s). Statistics with Confidence. London: British Medical Journal, 1995:50-63.

\section{Nuesch 2010}

Nüesch E, Trelle S, Reichenbach S, Rutjes AW, Tschannen B, Altman DG, et al. Small study effects in meta-analyses of osteoarthritis trials: meta-epidemiological study. BMJ 2010;341:c3515. [DOI: 10.1136/bmj.c3515]

\section{PACT 2010}

Prescription Cost Analysis England. The NHS Information Centre for Health and Social Care 2010. [ISBN: 978-1-84636-542-3]

\section{Patrono 2009}

Patrono C, Baigent C. Low-dose aspirin, coxibs, and other NSAIDS: a clinical mosaic emerges. Molecular Interventions 2009;9(1):31-9.

\section{RevMan 2012 [Computer program]}

The Nordic Cochrane Centre, The Cochrane Collaboration. Review Manager (RevMan). Version 5.2. Copenhagen: The Nordic Cochrane Centre, The Cochrane Collaboration, 2012.

\section{Roy 2010}

Roy YM, Derry S, Moore RA. Single dose oral lumiracoxib for postoperative pain in adults. Cochrane Database of Systematic Reviews 2010, Issue 7. [DOI: 10.1002/14651858.CD006865.pub2]

\section{Ruff 2011}

Ruff CT, Morrow DA, Jarolim P, Ren F, Contant CF, Kaur A, et al. Evaluation of NT-proBNP and high sensitivity C-reactive protein for predicting cardiovascular risk in patients with arthritis taking longterm nonsteroidal antiinflammatory drugs. Journal of Rheumatology 2011;38(6):1071-8. [DOI: 10.3899/ jrheum.100880]

\section{Straube 2005}

Straube S, Derry S, McQuay HJ, Moore RA. Effect of preoperative Cox-II-selective NSAIDs (coxibs) on postoperative outcomes: a systematic review of randomized studies. Acta Anaesthesiologica Scandinavica 2005;49(5):601-13.

\section{Toms 2008}

Toms L, McQuay HJ, Derry S, Moore RA. Single dose oral paracetamol (acetaminophen) for postoperative pain in adults Cochrane Database of Systematic Reviews 2008, Issue 4. [DOI: 10.1002/14651858.CD004602]

\section{Tramèr 1997}

Tramèr MR, Reynolds DJ, Moore RA, McQuay HJ. Impact of covert publication on meta-analysis: a case study. BMJ (Clinical research Ed.) 1997;315(7109):635-40. 
CHARACTERISTICS OF STUDIES

Characteristics of included studies [ordered by study ID]

Cheung 2007

Methods $\quad$ RCT, DB single oral dose, 3 parallel groups

Medication administered when baseline pain reached a moderate to severe intensity

Pain assessed at $0,15,30,45,60,90$ mins then hourly up to $12 \mathrm{~h}$, and at 16 and $24 \mathrm{~h}$

\begin{tabular}{ll}
\hline Participants & Impacted third molar extraction \\
& Mean age 22 years \\
& $\mathrm{N}=171$ \\
$\mathrm{M}=77, \mathrm{~F}=94$
\end{tabular}

$\begin{array}{ll}\text { Interventions } & \text { Celecoxib } 400 \mathrm{mg}, \mathrm{n}=57 \\ & \text { Ibuprofen } 400 \mathrm{mg}, \mathrm{n}=57 \\ & \text { Placebo, } \mathrm{n}=57\end{array}$

\begin{tabular}{ll}
\hline Pl: std 4-point scale \\
PR: std 5-point scale \\
Time to use of rescue medication \\
Number of participants using rescue medication \\
Number of participants reporting any adverse event and serious adverse events \\
Number of participants withdrawing due to adverse event
\end{tabular}

\begin{tabular}{ll}
\hline Notes & Oxford Quality Score: R2, DB2, W1 \\
Participants asked to refrain from rescue medication for $1 \mathrm{~h}$
\end{tabular}

\section{Risk of bias}

\begin{tabular}{|c|c|c|}
\hline Bias & Authors' judgement & Support for judgement \\
\hline $\begin{array}{l}\text { Random sequence genera- } \\
\text { tion (selection bias) }\end{array}$ & Low risk & $\begin{array}{l}\text { "computer-generated randomization schedule, prepared before the start of } \\
\text { the study" }\end{array}$ \\
\hline $\begin{array}{l}\text { Allocation concealment } \\
\text { (selection bias) }\end{array}$ & Low risk & $\begin{array}{l}\text { Medication supplied in patient-specific carton. Identity of assignment con- } \\
\text { tained in concealed section of label, which was removed at dispensing, and at- } \\
\text { tached to patient case report form }\end{array}$ \\
\hline $\begin{array}{l}\text { Blinding (performance } \\
\text { bias and detection bias) } \\
\text { All outcomes }\end{array}$ & Low risk & $\begin{array}{l}\text { Double-blind method. Placebo capsules or tablets identical in number and ap- } \\
\text { pearance to active treatments }\end{array}$ \\
\hline $\begin{array}{l}\text { Incomplete outcome data } \\
\text { (attrition bias) } \\
\text { All outcomes }\end{array}$ & Low risk & All participants accounted for; analysis appropriate for relevant time interval \\
\hline Size & Unclear risk & Small treatment group size (57 participants) \\
\hline
\end{tabular}

Doyle 2002

$\begin{array}{ll}\text { Methods } & \text { RCT, DB single oral and multiple oral dose, } 3 \text { parallel groups } \\ \text { Medication administered when baseline pain reached a moderate to severe intensity } \\ \text { Pain assessed at } 0,15,30,45,60,90 \text { mins then hourly up to } 12 \mathrm{~h}\end{array}$

\begin{tabular}{ll}
\hline Participants & Impacted third molar extraction \\
& Mean age 22 years \\
\hline
\end{tabular}


Doyle 2002 (Continued)

$$
\begin{aligned}
& N=174 \\
& M=75, F=99
\end{aligned}
$$

\begin{tabular}{|c|c|c|}
\hline Interventions & \multicolumn{2}{|c|}{$\begin{array}{l}\text { Celecoxib } 200 \mathrm{mg}, \mathrm{n}=74 \\
\text { Ibuprofen liquigel } 400 \mathrm{mg}, \mathrm{n}=74 \\
\text { Placebo, } \mathrm{n}=26\end{array}$} \\
\hline Outcomes & \multicolumn{2}{|c|}{$\begin{array}{l}\text { PI: 4-point scale } \\
\text { PR: 5-point scale } \\
\text { PGE: std 5-point scale (patients reporting "very good" or "excellent") } \\
\text { Time to use of rescue medication } \\
\text { Number of participants using rescue medication } \\
\text { Number of participants reporting any adverse event and serious adverse events } \\
\text { Number of participants withdrawing due to adverse event }\end{array}$} \\
\hline Notes & \multicolumn{2}{|c|}{$\begin{array}{l}\text { Oxford Quality Score: R2, DB2, W1 } \\
\text { Participants asked to refrain from rescue medication for } 1 \mathrm{~h}\end{array}$} \\
\hline \multicolumn{3}{|l|}{ Risk of bias } \\
\hline Bias & Authors' judgement & Support for judgement \\
\hline $\begin{array}{l}\text { Random sequence genera- } \\
\text { tion (selection bias) }\end{array}$ & Low risk & "computer-generated allocation schedule" \\
\hline $\begin{array}{l}\text { Allocation concealment } \\
\text { (selection bias) }\end{array}$ & Unclear risk & Not described \\
\hline $\begin{array}{l}\text { Blinding (performance } \\
\text { bias and detection bias) } \\
\text { All outcomes }\end{array}$ & Low risk & $\begin{array}{l}\text { Double-dummy method. "The appearance, presentation and labelling of the } \\
\text { placebo formulations were identical to those of the corresponding active } \\
\text { drugs" }\end{array}$ \\
\hline $\begin{array}{l}\text { Incomplete outcome data } \\
\text { (attrition bias) } \\
\text { All outcomes }\end{array}$ & Low risk & Participants accounted for; analysis appropriate for relevant time interval \\
\hline Size & Unclear risk & Small treatment group size (74 active, 26 placebo participants) \\
\hline
\end{tabular}

\section{Fricke 2008}

\begin{tabular}{ll}
\hline Methods & $\begin{array}{l}\text { RCT, DB, double-dummy, single oral dose, } 3 \text { parallel groups } \\
\text { Medication administered when baseline pain reached a moderate to severe intensity } \\
\text { Pain assessed at } 0,15,30,45,60,90 \text { mins then hourly up to } 12 \mathrm{~h} \text {, and at } 24 \mathrm{~h}\end{array}$ \\
\hline Participants & $\begin{array}{l}\text { Impacted third molar extraction } \\
\text { Mean age } 23 \text { years } \\
\mathrm{N}=364 \\
\mathrm{M}=133, \mathrm{~F}=231\end{array}$ \\
\hline Interventions & $\begin{array}{l}\text { Celecoxib } 400 \mathrm{mg}, \mathrm{n}=156 \\
\text { Lumiracoxib } 400 \mathrm{mg}, \mathrm{n}=156 \\
\text { Placebo, } \mathrm{n}=52\end{array}$ \\
\hline Outcomes & Pl: std 4-point scale \\
PR: std 5-point scale \\
Time to use of rescue medication \\
Number of participants using rescue medication
\end{tabular}


Fricke 2008 (Continued)

Number of participants reporting any adverse event and serious adverse events

Number of participants withdrawing due to adverse event

\begin{tabular}{ll}
\hline Notes & Oxford Quality Score: R2, DB1, W1 \\
& Participants permitted to use rescue medication at any time
\end{tabular}

\section{Risk of bias}

\begin{tabular}{|c|c|c|}
\hline Bias & Authors' judgement & Support for judgement \\
\hline $\begin{array}{l}\text { Random sequence genera- } \\
\text { tion (selection bias) }\end{array}$ & Low risk & Computer-generated \\
\hline $\begin{array}{l}\text { Allocation concealment } \\
\text { (selection bias) }\end{array}$ & Low risk & Remote, automated allocation to randomisation numbers \\
\hline $\begin{array}{l}\text { Blinding (performance } \\
\text { bias and detection bias) } \\
\text { All outcomes }\end{array}$ & Unclear risk & Not described \\
\hline $\begin{array}{l}\text { Incomplete outcome data } \\
\text { (attrition bias) } \\
\text { All outcomes }\end{array}$ & Low risk & Participants accounted for; analysis appropriate for relevant time interval \\
\hline Size & Unclear risk & Small treatment group size (156 active, 52 placebo participants) \\
\hline
\end{tabular}

\section{Gimbel 2001}

\begin{tabular}{ll}
\hline Methods & $\begin{array}{l}\text { RCT, DB single oral and multiple oral dose, } 3 \text { parallel groups } \\
\text { Medication administered when baseline pain reached a moderate to severe intensity } \\
\text { Pain assessed at } 0,15,30,45,60,90 \text { mins then hourly up to } 8 \text { h. Multiple-dose phase continued over } 3 \\
\text { days }\end{array}$ \\
\hline Participants & $\begin{array}{l}\text { Orthopaedic surgery (uncomplicated) } \\
\text { Mean age } 46 \text { years } \\
\mathrm{N}=418 \\
\mathrm{M}=165, \mathrm{~F}=253\end{array}$ \\
\hline Celecoxib $200 \mathrm{mg}, \mathrm{n}=141$ \\
Hydrocodone $10 \mathrm{mg}+$ acetaminophen $1000 \mathrm{mg}, \mathrm{n}=136$ \\
Placebo, $\mathrm{n}=141$
\end{tabular}

\section{Risk of bias}

\section{Bias}

\section{Authors' judgement Support for judgement}


Gimbel 2001 (Continued)

\begin{tabular}{lll}
$\begin{array}{l}\text { Random sequence genera- } \\
\text { tion (selection bias) }\end{array}$ & Unclear risk & Not described \\
\hline $\begin{array}{l}\text { Allocation concealment } \\
\text { (selection bias) }\end{array}$ & Unclear risk & Not described \\
\hline $\begin{array}{l}\text { Blinding (performance } \\
\text { bias and detection bias) } \\
\text { All outcomes }\end{array}$ & Unclear risk & Not described \\
\hline
\end{tabular}

\begin{tabular}{lll}
\hline $\begin{array}{l}\text { Incomplete outcome data } \\
\text { (attrition bias) } \\
\text { All outcomes }\end{array}$ & Low risk & Participants accounted for; analysis appropriate for relevant time interval \\
\hline Size & Unclear risk & Small treatment group size (136 to 141 participants) \\
\hline
\end{tabular}

IND2-08-03

\begin{tabular}{ll}
\hline Methods & Randomised, double-blind, single-dose, parallel-group, duration $8 \mathrm{~h}$ \\
& Medication given when pain $\geq$ moderate \\
\hline Participants & Surgical removal of $\geq 2$ impacted third molars \\
& M and F, age 18 to 50 years \\
& $\mathrm{N}=203$ \\
\hline Interventions & Celecoxib $400 \mathrm{mg}, \mathrm{n}=51$ \\
& Indomethacin $20 \mathrm{mg}, \mathrm{n}=50$ \\
Indomethacin $40 \mathrm{mg}, \mathrm{n}=51$ \\
Placebo, $\mathrm{n}=51$ \\
\hline $\begin{array}{l}\text { PI: std 4-point scale } \\
\text { PR: std 5-point scale } \\
\text { Number of participants reporting any adverse event and serious adverse events } \\
\text { Number of participants withdrawing due to adverse event }\end{array}$ \\
$\begin{array}{l}\text { Clinical trial summary } \\
\text { Oxford Quality Score: } \mathrm{R} 1, \text { DB1, W1 }\end{array}$ \\
\hline Notes
\end{tabular}

\section{Risk of bias}

\begin{tabular}{lll}
\hline Bias & Authors' judgement & Support for judgement \\
\hline $\begin{array}{l}\text { Random sequence genera- } \\
\text { tion (selection bias) }\end{array}$ & Unclear risk & Not described \\
\hline $\begin{array}{l}\text { Allocation concealment } \\
\text { (selection bias) }\end{array}$ & Unclear risk & Not described \\
\hline $\begin{array}{l}\text { Blinding (performance } \\
\text { bias and detection bias) }\end{array}$ & Unclear risk & Not described \\
\hline
\end{tabular}


IND2-08-03 (Continued)

All outcomes

\begin{tabular}{lll}
\hline $\begin{array}{l}\text { Incomplete outcome data } \\
\text { (attrition bias) } \\
\text { All outcomes }\end{array}$ & Unclear risk & Unclear how data from withdrawals were handled \\
\hline Size & Unclear risk & Small treatment group size (50 to 51 participants) \\
\hline
\end{tabular}

\section{Kellstein 2004}

\begin{tabular}{|c|c|c|}
\hline Methods & \multicolumn{2}{|c|}{$\begin{array}{l}\mathrm{RCT}, \mathrm{DB} \text {, double-dummy, single oral dose, } 4 \text { parallel groups } \\
\text { Medication administered when baseline pain reached a moderate to severe intensity } \\
\text { Pain assessed at } 0,15,30,45,60,90 \text { mins then hourly up to } 12 \mathrm{~h} \text {, and at } 24 \mathrm{~h}\end{array}$} \\
\hline Participants & \multicolumn{2}{|c|}{$\begin{array}{l}\text { Impacted third molar extraction } \\
\text { Mean age } 22 \text { years } \\
N=355 \\
M=112, F=243\end{array}$} \\
\hline Interventions & \multicolumn{2}{|c|}{$\begin{array}{l}\text { Celecoxib } 200 \mathrm{mg}, \mathrm{n}=101 \\
\text { Lumiracoxib } 400 \mathrm{mg}, \mathrm{n}=101 \\
\text { Rofecoxib } 50 \mathrm{mg}, \mathrm{n}=102 \\
\text { Placebo, } \mathrm{n}=51\end{array}$} \\
\hline Outcomes & \multicolumn{2}{|c|}{$\begin{array}{l}\text { PI: std 4-point scale } \\
\text { PR: std 5-point scale } \\
\text { PGE: std 5-point scale } \\
\text { Time to use of rescue medication } \\
\text { Number of participants using rescue medication }\end{array}$} \\
\hline Notes & \multicolumn{2}{|c|}{$\begin{array}{l}\text { Oxford Quality Score: R1, DB2, W1 } \\
\text { Participants asked to refrain from rescue medication for } 1 \mathrm{~h}\end{array}$} \\
\hline \multicolumn{3}{|l|}{ Risk of bias } \\
\hline Bias & Authors' judgement & Support for judgement \\
\hline $\begin{array}{l}\text { Random sequence genera- } \\
\text { tion (selection bias) }\end{array}$ & Unclear risk & Not described \\
\hline $\begin{array}{l}\text { Allocation concealment } \\
\text { (selection bias) }\end{array}$ & Unclear risk & Not described \\
\hline $\begin{array}{l}\text { Blinding (performance } \\
\text { bias and detection bias) } \\
\text { All outcomes }\end{array}$ & Low risk & $\begin{array}{l}\text { Double-dummy method. Placebo capsules and tablets matching correspond- } \\
\text { ing active treatments }\end{array}$ \\
\hline $\begin{array}{l}\text { Incomplete outcome data } \\
\text { (attrition bias) } \\
\text { All outcomes }\end{array}$ & Low risk & Participants accounted for; analysis appropriate for relevant time interval \\
\hline Size & Unclear risk & Small treatment group size (100 to 101 active, 51 placebo participants) \\
\hline
\end{tabular}


Malmstrom 1999

\begin{tabular}{|c|c|c|}
\hline Methods & \multicolumn{2}{|c|}{$\begin{array}{l}\mathrm{RCT}, \mathrm{DB} \text { single oral dose and multiple oral dose, } 4 \text { parallel groups } \\
\text { Medication administered when baseline pain reached a moderate to severe intensity } \\
\text { Pain assessed at } 0,15,30,45,60 \text {, and } 90 \text { mins, then at } 2,3,4,5,6,7,8 \mathrm{~h}\end{array}$} \\
\hline Participants & \multicolumn{2}{|c|}{$\begin{array}{l}\text { Impacted third molar extraction } \\
\text { Mean age } 23 \text { years } \\
N=272 \\
M=100, F=172\end{array}$} \\
\hline Interventions & \multicolumn{2}{|c|}{$\begin{array}{l}\text { Celecoxib } 200 \mathrm{mg}, \mathrm{n}=91 \\
\text { Rofecoxib } 50 \mathrm{mg}, \mathrm{n}=90 \\
\text { Ibuprofen } 400 \mathrm{mg}, \mathrm{n}=46 \\
\text { Placebo, } \mathrm{n}=45\end{array}$} \\
\hline Outcomes & \multicolumn{2}{|c|}{$\begin{array}{l}\text { PI: std 4-point scale } \\
\text { PR: std 5-point scale } \\
\text { PGE: std 5-point scale } \\
\text { Time to use of rescue medication } \\
\text { Number of participants using rescue medication }\end{array}$} \\
\hline Notes & \multicolumn{2}{|c|}{$\begin{array}{l}\text { Oxford Quality Score: R2, DB2, W1 } \\
\text { Participants asked to refrain from rescue medication for } 1.5 \mathrm{~h}\end{array}$} \\
\hline \multicolumn{3}{|l|}{ Risk of bias } \\
\hline Bias & Authors' judgement & Support for judgement \\
\hline $\begin{array}{l}\text { Random sequence genera- } \\
\text { tion (selection bias) }\end{array}$ & Low risk & "computer-generated allocation schedule" \\
\hline $\begin{array}{l}\text { Allocation concealment } \\
\text { (selection bias) }\end{array}$ & Unclear risk & Not described \\
\hline $\begin{array}{l}\text { Blinding (performance } \\
\text { bias and detection bias) } \\
\text { All outcomes }\end{array}$ & Low risk & $\begin{array}{l}\text { Double-dummy method, using marketed tablet or capsule formulations or } \\
\text { matching placebos }\end{array}$ \\
\hline $\begin{array}{l}\text { Incomplete outcome data } \\
\text { (attrition bias) } \\
\text { All outcomes }\end{array}$ & Low risk & Participants accounted for; analysis appropriate for relevant time interval \\
\hline Size & Unclear risk & $\begin{array}{l}\text { Small treatment group size ( } 90,91 \text { coxib, } 45,46 \text { ibuprofen, and placebo partic- } \\
\text { ipants) }\end{array}$ \\
\hline
\end{tabular}

\section{Malmstrom 2002}

\begin{tabular}{ll}
\hline Methods & RCT, DB single oral dose, 5 parallel groups \\
& $\begin{array}{l}\text { Medication administered when baseline pain reached a moderate to severe intensity } \\
\text { Pain assessed at } 0,15,30,45,60 \text {, and } 90 \text { mins, then at } 2,3,4,5,6,7,8 \text {, and } 12 \mathrm{~h}\end{array}$ \\
\hline Participants & $\begin{array}{l}\text { Impacted third molar extraction } \\
\text { Mean age } 22 \text { years } \\
\mathrm{N}=482 \\
\mathrm{M}=124, \mathrm{~F}=358\end{array}$ \\
\hline Interventions & Celecoxib $400 \mathrm{mg}, \mathrm{n}=151$
\end{tabular}


Malmstrom 2002 (Continued)

Celecoxib $200 \mathrm{mg}, \mathrm{n}=90$

Rofecoxib $50 \mathrm{mg}, \mathrm{n}=150$

Ibuprofen $400 \mathrm{mg}, \mathrm{n}=45$

Placebo, $\mathrm{n}=45$

\begin{tabular}{ll}
\hline Outcomes & PI: std 4-point scale \\
& PR: std 5-point scale \\
& PGE: std 5-point scale \\
& Time to use of rescue medication \\
& Number of participants using rescue medication \\
\hline Notes & Oxford Quality Score: R2, DB2, W1 \\
& Participants asked to refrain from rescue medication for $1.5 \mathrm{~h}$
\end{tabular}

\section{Risk of bias}

\begin{tabular}{lll}
\hline Bias & Authors' judgement & Support for judgement \\
\hline $\begin{array}{l}\text { Random sequence genera- } \\
\text { tion (selection bias) }\end{array}$ & Low risk & "computer-generated allocation schedule" \\
\hline $\begin{array}{l}\text { Allocation concealment } \\
\text { (selection bias) }\end{array}$ & Low risk & $\begin{array}{l}\text { Participants allocated to next randomisation number (lowest for moderate } \\
\text { pain, highest for severe pain) }\end{array}$ \\
\hline $\begin{array}{l}\text { Blinding (performance } \\
\text { bias and detection bias) } \\
\text { All outcomes }\end{array}$ & Low risk & $\begin{array}{l}\text { Double-dummy method. Each active treatment had matching placebo tablets } \\
\text { or capsules }\end{array}$ \\
\hline $\begin{array}{l}\text { Incomplete outcome data } \\
\text { (attrition bias) } \\
\text { All outcomes }\end{array}$ & Low risk & \begin{tabular}{l} 
Participants accounted for; analysis appropriate for relevant time interval \\
\hline Size
\end{tabular} \\
\hline
\end{tabular}

\section{Manvelian 2012}

\begin{tabular}{ll}
\hline Methods & Randomised, double-blind, single-dose, parallel-group, duration $12 \mathrm{~h}$ \\
& Medication given when pain $\geq$ moderate \\
& Pain assessed at $0,0.25,0.5,0.75,1,1.5,2,3,4,5,6,7,8,10,12 \mathrm{~h}$ \\
\hline Participants & Surgical removal of $\geq 2$ impacted third molars \\
& $\mathrm{M}$ and $\mathrm{F}$, age 18 to 50 years \\
& $\mathrm{N}=202$ \\
\hline Interventions & Celecoxib $400 \mathrm{mg}, \mathrm{n}=51$ \\
& Diclofenac, nano-formulated $18 \mathrm{mg}, \mathrm{n}=49$ \\
& Diclofenac, nano-formulated $35 \mathrm{mg}, \mathrm{n}=51$ \\
& Placebo, $\mathrm{n}=51$ \\
\hline Outcomes & Pl: std 4-point scale
\end{tabular}


Manvelian 2012 (Continued)

PR: std 5-point scale

Time to use of rescue medication

Number of participants reporting any adverse event and serious adverse events

Number of participants withdrawing due to adverse event

$\begin{array}{ll}\text { Notes } & \text { Oxford Quality Score: R1, D1, W0 } \\ \text { Participants asked to refrain from rescue medication for } 1 \mathrm{~h}\end{array}$

\section{Risk of bias}

\begin{tabular}{lll}
\hline Bias & Authors' judgement & Support for judgement \\
\hline $\begin{array}{l}\text { Random sequence genera- } \\
\text { tion (selection bias) }\end{array}$ & Unclear risk & Not described \\
\hline $\begin{array}{l}\text { Allocation concealment } \\
\text { (selection bias) }\end{array}$ & Unclear risk & Not described \\
\hline $\begin{array}{l}\text { Blinding (performance } \\
\text { bias and detection bias) } \\
\text { All outcomes }\end{array}$ & Unclear risk & Not described \\
\hline $\begin{array}{l}\text { Incomplete outcome data } \\
\text { (attrition bias) } \\
\text { All outcomes }\end{array}$ & Unclear risk & Unclear how data from withdrawals were handled \\
\hline $\begin{array}{l}\text { Size } \\
\end{array}$ & Unclear risk & Small treatment group size (49 to 51 participants) \\
\hline
\end{tabular}

Moberly 2007

$\begin{array}{ll}\text { Methods } & \text { RCT, DB single oral dose, } 6 \text { parallel groups } \\ \text { Medication administered when baseline pain reached a moderate to severe intensity } \\ \text { Pain assessed at } 0,15,30,45,60 \text {, and } 90 \text { mins, then at } 2,3,4,5,6,7,8,10,12 \text {, and } 24 \mathrm{~h}\end{array}$

\begin{tabular}{ll}
\hline Participants & Impacted third molar extraction \\
& Mean age 22 years \\
& $\mathrm{N}=304$ \\
& \\
\hline Interventions & Celecoxib $400 \mathrm{mg}, \mathrm{n}=51$ \\
& Placebo, $\mathrm{n}=52$ \\
& CS-706 also tested at 10, 50, 100, $200 \mathrm{mg}$ \\
\hline Outcomes & Pl: std 4-point scale \\
& PR: std 5-point scale \\
& PGE: std 5-point scale \\
& Time to use of rescue medication \\
& Number of participants using rescue medication \\
\hline Notes & Oxford Quality Score: $\mathrm{R} 1$, DB2, $\mathrm{W} 1$ \\
& Participants asked to refrain from rescue medication for $1.5 \mathrm{~h}$ \\
\hline
\end{tabular}

\section{Risk of bias}

\section{Bias}

\section{Authors' judgement Support for judgement}


Moberly 2007 (Continued)
Random sequence genera-
Unclear risk
Not described tion (selection bias)

\begin{tabular}{lll}
\hline $\begin{array}{l}\text { Allocation concealment } \\
\text { (selection bias) }\end{array}$ & Low risk & $\begin{array}{l}\text { Investigator, all study staff and related personnel were unaware of treatment } \\
\text { assignment }\end{array}$ \\
\hline $\begin{array}{l}\text { Blinding (performance } \\
\text { bias and detection bias) }\end{array}$ & Low risk & $\begin{array}{l}\text { Double-dummy method. Matching tablets for CS-706 and corresponding } \\
\text { placebo. Celecoxib and corresponding placebo capsules differed in markings, } \\
\text { so participant blindfolded and treatment administered by a third party. }\end{array}$
\end{tabular}

Incomplete outcome data $\quad$ Unclear risk Participants accounted for; analysis appropriate for relevant time interval
(attrition bias)

(attrition bias)

All outcomes

\begin{tabular}{ll}
\hline Size $\quad$ Unclear risk $\quad$ Small treatment group size (50 to 51 participants) \\
\hline
\end{tabular}

RCT - randomised controlled trial; R - randomisation; DB - double blind; W - withdrawals; PI - pain intensity; PR - pain relief; PGE - patient global evaluation; std - standard

Characteristics of excluded studies [ordered by study ID]

\begin{tabular}{ll}
\hline Study & Reason for exclusion \\
\hline Saito 2012 & No single-dose data \\
\hline Salo 2003 & No placebo group; included participants with musculoskeletal injuries, not postoperative pain \\
\hline White 2007 & Not established moderate to severe pain \\
\hline
\end{tabular}

Characteristics of studies awaiting assessment [ordered by study ID]

177-CL-102

\begin{tabular}{ll}
\hline Methods & Randomised, double-blind, parallel-group, duration 2 days \\
& Medication given when pain $\geq$ moderate \\
\hline Participants & Postoperative pain \\
& M and F, age $\geq 20$ years \\
& $\mathrm{N}=616$ \\
\hline Interventions & Celecoxib \\
Etodolac \\
Placebo \\
Doses not given
\end{tabular}

\begin{tabular}{ll}
\hline Outcomes & Patient impression \\
& Pain intensity, pain intensity difference \\
& Discontinuation due to lack of efficacy
\end{tabular}


177-CL-102 (Continued)

\section{Adverse events}

Notes May not have single-dose data

Primary completion date November 2010

\section{ARRY-797-221}

\section{Methods}

\section{Participants}

Interventions

\section{Outcomes}

\section{Notes}

Mentioned as "recently completed postoperative pain study" in ARRY-797-22

\section{ARRY-797-222}

\begin{tabular}{ll}
\hline Methods & Randomised, double-blind, single-dose, parallel-group, duration $6 \mathrm{~h}$ (to second dose) \\
& Medication given when pain $\geq$ moderate \\
\hline Participants & Surgical removal of $\geq 3$ third molars (1 mandibular and impacted) \\
& M and F, age 18 to 50 years \\
& $\mathrm{N}=250$ \\
\hline Interventions & Celecoxib $400 \mathrm{mg}$ \\
& ARRY-31797 $200 \mathrm{mg}$ \\
& ARRY-31797 $400 \mathrm{mg}$ \\
ARRY-31797 $600 \mathrm{mg}$ \\
Placebo \\
\hline TOTPAR (dose 1 ) \\
Use of rescue medication \\
Adverse events \\
\hline Primary completion June 2008 \\
\hline Notes
\end{tabular}

\section{Shirota 2001}

Methods

\section{Participants}


Shirota 2001 (Continued)

Interventions

Outcomes

\section{DATA AND ANALYSES}

Comparison 1. Celecoxib $200 \mathrm{mg}$ versus placebo

\begin{tabular}{lllll}
\hline Outcome or subgroup title & No. of studies & $\begin{array}{l}\text { No. of partici- } \\
\text { pants }\end{array}$ & Statistical method & Effect size \\
\hline $\begin{array}{l}1 \text { At least 50\% pain relief } \\
\text { over 4-6 hours }\end{array}$ & 4 & 705 & Risk Ratio (M-H, Fixed, 95\% Cl) & $3.49[2.40,5.06]$ \\
\hline $\begin{array}{lllll}1.1 \text { Dental pain } \\
\text { 1.2 Postsurgical pain }\end{array}$ & 3 & 423 & Risk Ratio (M-H, Fixed, 95\% Cl) & $15.86[5.14,48.99]$ \\
\hline $\begin{array}{l}\text { 2 Use of rescue medication } \\
\text { over 24 hours }\end{array}$ & 2 & 282 & Risk Ratio (M-H, Fixed, 95\% Cl) & $1.83[1.26,2.68]$ \\
\hline 3 Any adverse event & 4 & 271 & Risk Ratio (IV, Fixed, 95\% Cl) & $0.78[0.70,0.86]$ \\
\hline 3.1 Dental & 3 & 669 & Risk Ratio (M-H, Fixed, 95\% Cl) & $0.90[0.63,1.29]$ \\
\hline 3.2 Orthopaedic & 1 & 387 & Risk Ratio (M-H, Fixed, 95\% Cl) & $0.97[0.63,1.49]$ \\
\hline
\end{tabular}

Analysis 1.1. Comparison 1 Celecoxib $200 \mathrm{mg}$ versus placebo, Outcome 1 At least 50\% pain relief over 4-6 hours.

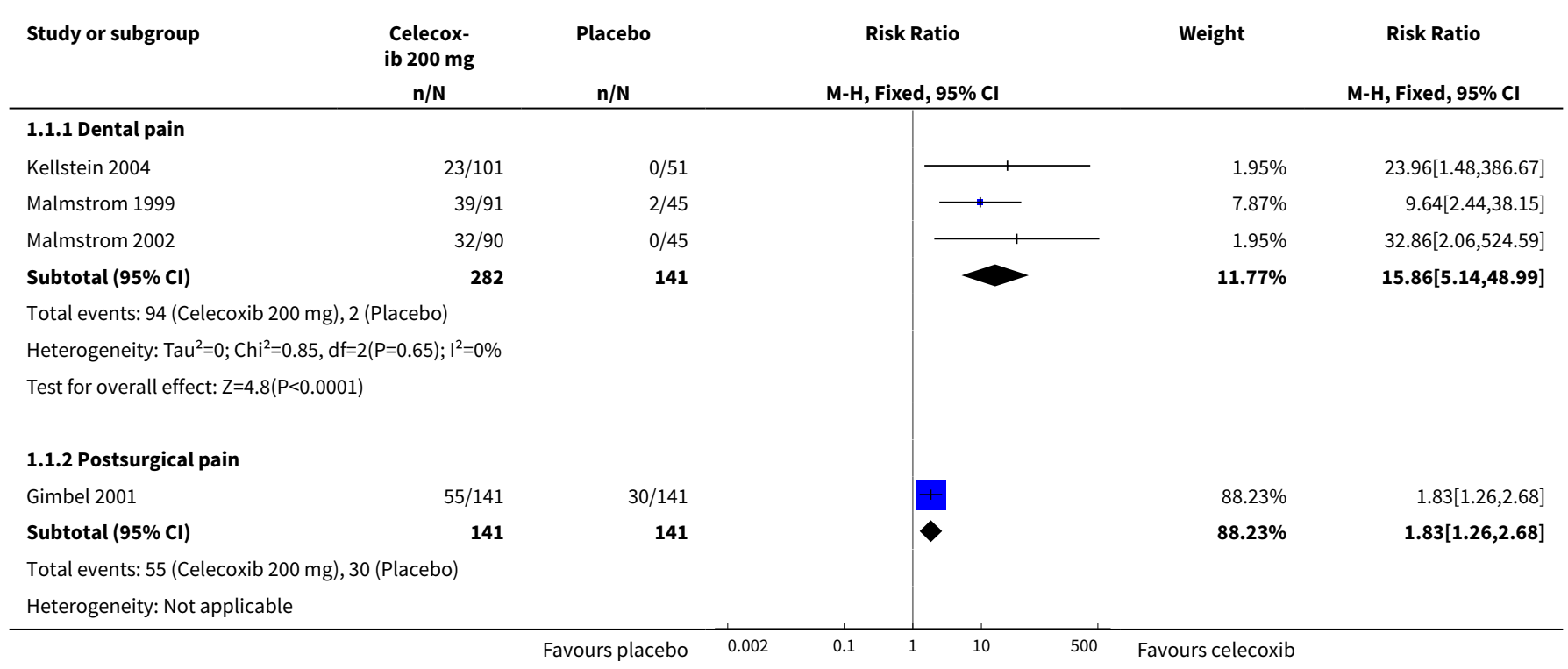




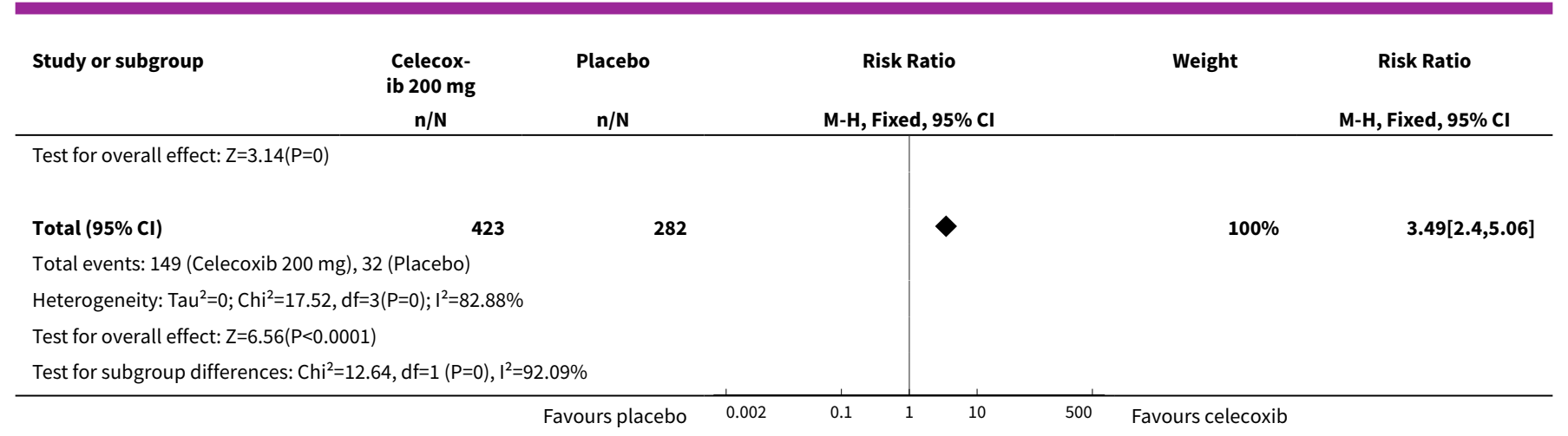

Analysis 1.2. Comparison 1 Celecoxib $200 \mathrm{mg}$ versus placebo, Outcome 2 Use of rescue medication over 24 hours.

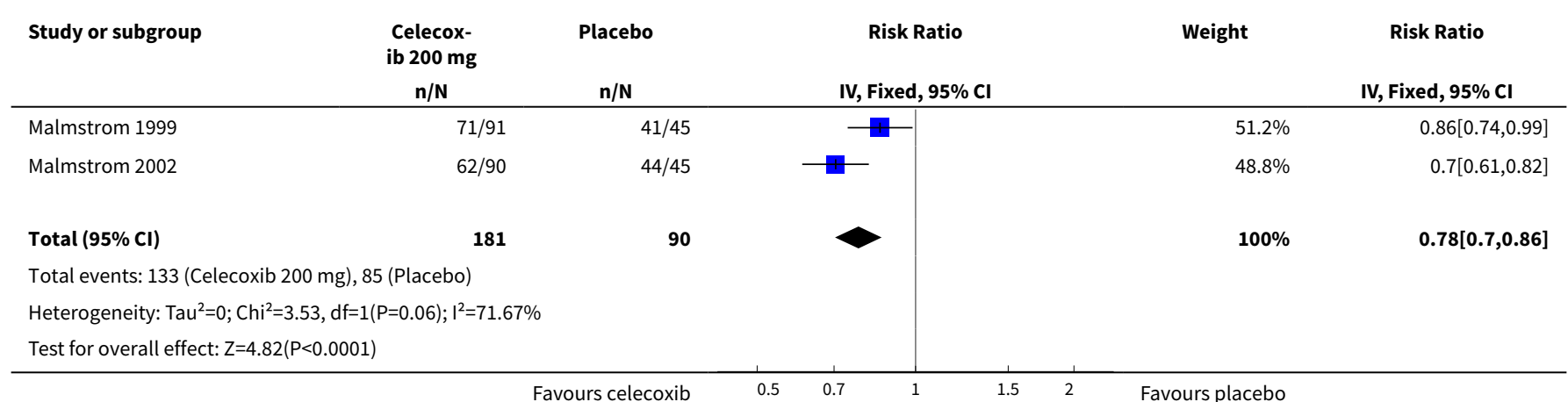

Analysis 1.3. Comparison 1 Celecoxib $200 \mathrm{mg}$ versus placebo, Outcome 3 Any adverse event.

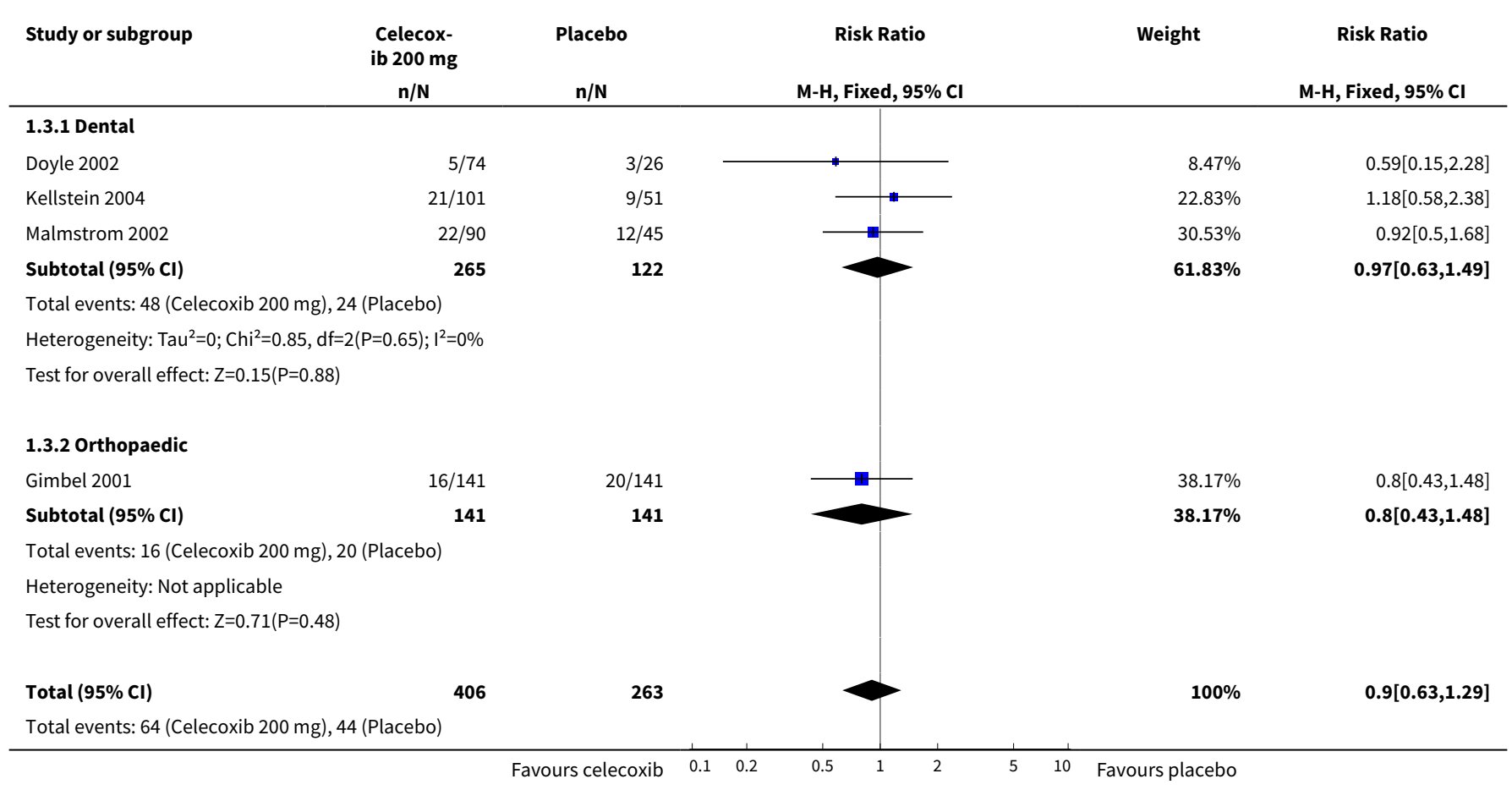




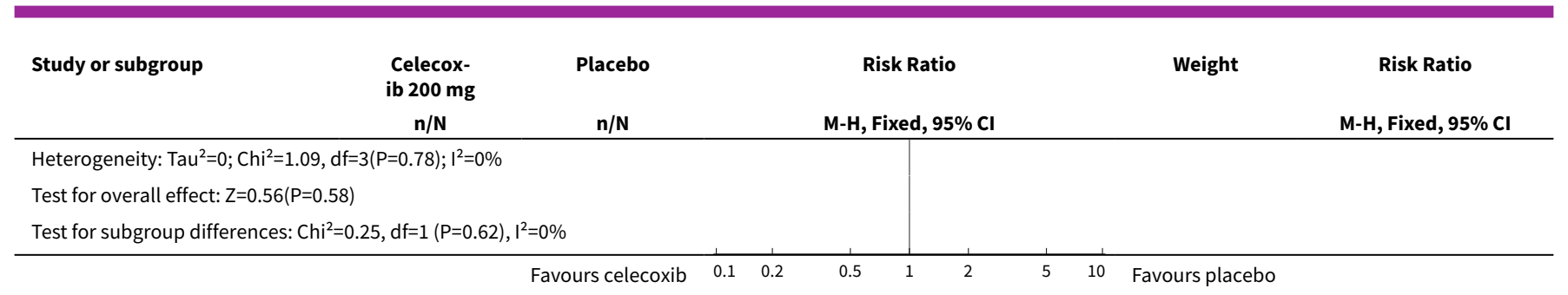

\section{Comparison 2. Celecoxib $\mathbf{4 0 0} \mathbf{m g}$ versus placebo}

\begin{tabular}{lllll}
\hline Outcome or subgroup title & No. of studies & $\begin{array}{l}\text { No. of partici- } \\
\text { pants }\end{array}$ & Statistical method & Effect size \\
\hline $\begin{array}{l}1 \text { At least 50\% pain relief over 4-6 } \\
\text { hours, dental pain }\end{array}$ & 5 & 722 & $\begin{array}{l}\text { Risk Ratio (M-H, Fixed, 95\% } \\
\text { Cl) }\end{array}$ & $10.26[5.70,18.47]$ \\
\hline $\begin{array}{l}2 \text { Use of rescue medication over 24 } \\
\text { hours }\end{array}$ & 3 & 518 & Risk Ratio (IV, Fixed, 95\% Cl) & $0.68[0.62,0.74]$ \\
\hline 3 Any adverse event & 6 & 725 & $\begin{array}{l}\text { Risk Ratio (M-H, Fixed, 95\% } \\
\text { Cl) }\end{array}$ & $1.00[0.84,1.17]$ \\
\hline
\end{tabular}

Analysis 2.1. Comparison 2 Celecoxib $400 \mathrm{mg}$ versus placebo, Outcome 1 At least 50\% pain relief over 4-6 hours, dental pain.

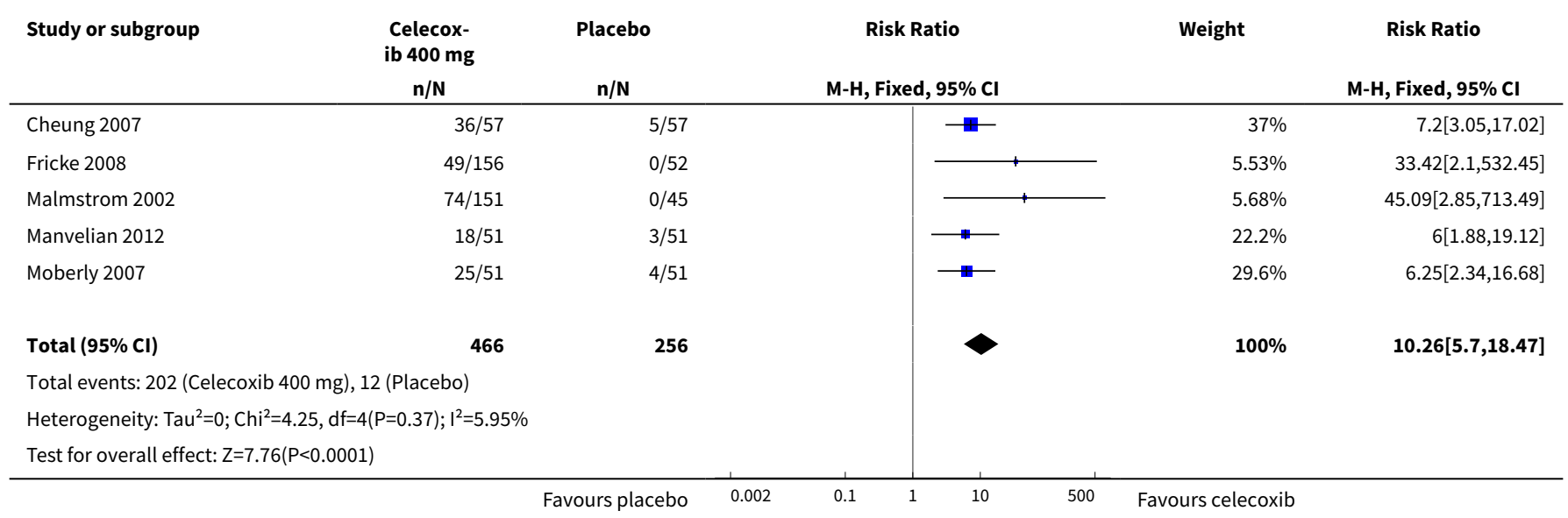

Analysis 2.2. Comparison 2 Celecoxib $400 \mathrm{mg}$ versus placebo, Outcome 2 Use of rescue medication over 24 hours.

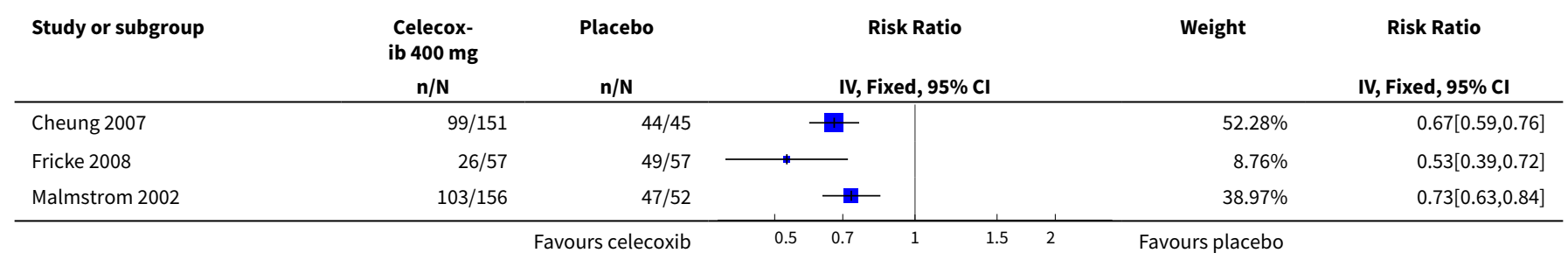




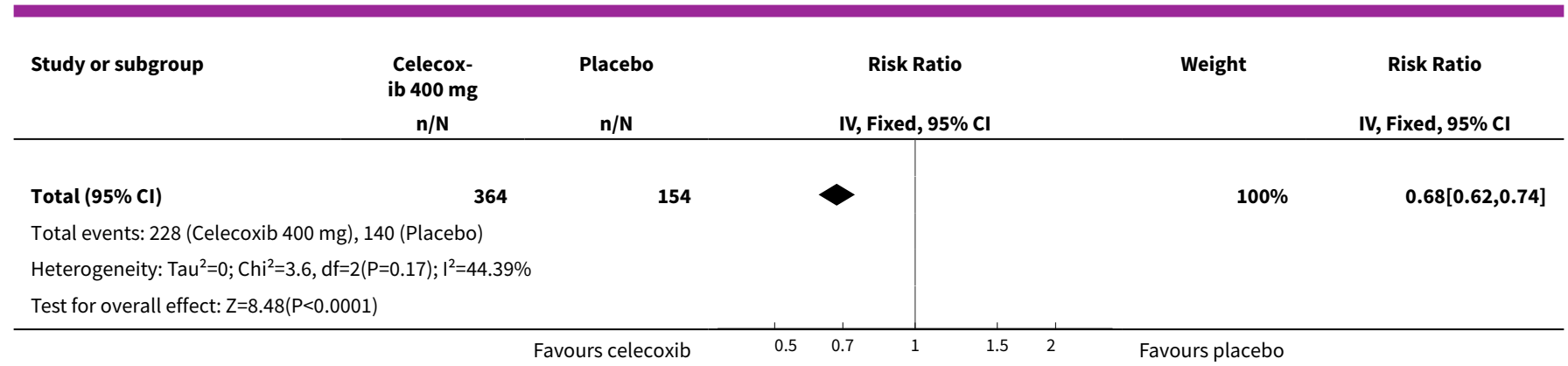

Analysis 2.3. Comparison 2 Celecoxib $400 \mathrm{mg}$ versus placebo, Outcome 3 Any adverse event.

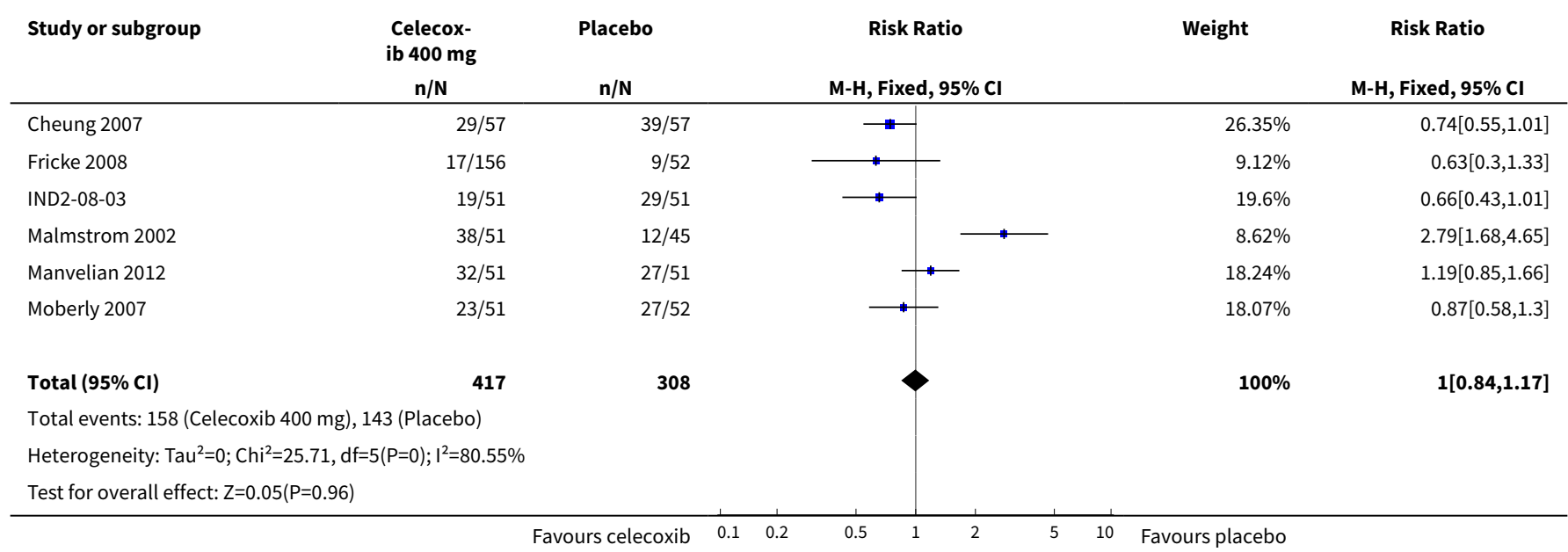

\section{APPENDICES}

\section{Appendix 1. MEDLINE via Ovid search strategy}

1. celecoxib.sh

2. (celecoxib OR celebrex OR Celebra OR Onsenal).ti.ab.kw.

3. 1 OR 2

4. PAIN, POSTOPERATIVE.sh

5. ((postoperative adj4 pain\$) or (post-operative adj4 pain\$) or post-operative-pain\$ or (post\$ NEAR pain\$) or (postoperative adj4 analgesi \$) or (post-perative adj4 analgesi\$) or ("post-operative analgesi\$")).ti,ab,kw.

6. ((post-surgical adj4 pain\$) or ("post surgical" adj4 pain\$) or (post-surgery adj4 pain\$)).ti,ab,kw.

7. (("pain-relief after surg\$") or ("pain following surg\$") or ("pain control after")).ti,ab,kw.

8. (("post surg\$" or post-surg\$) AND (pain\$ or discomfort)).ti,ab,kw.

9. ((pain\$ adj4 "after surg\$") or (pain\$ adj4 "after operat\$") or (pain\$ adj4 "follow\$ operat\$") or (pain\$ adj4 "follow\$ surg\$")).ti,ab,kw.

10. ((analgesi\$ adj4 "after surg\$") or (analgesi\$ adj4 "after operat\$") or (analgesi\$ adj4 "follow\$ operat\$") or (analgesi\$ adj4 "follow\$ surg \$")).ti,ab,kw.

$11.0 \mathrm{OR} / 4-10$

12.randomized controlled trial.pt.

13.controlled clinical trial.pt.

14.randomized.ab.

15. placebo.ab.

16.drug therapy.fs. 
17.randomly.ab.

18.trial.ab.

19.groups.ab.

20.OR/12-19

21.3 AND 11 AND 20

\section{Appendix 2. EMBASE via Ovid search strategy}

1. celecoxib.sh.

2. (celecoxib OR celebrex OR Celebra OR Onsenal).ti.ab.kw.

3. $O R / 1-2$

4. PAIN, POSTOPERATIVE.sh.

5. ((postoperative adj4 pain\$) or (post-operative adj4 pain\$) or post-operative-pain $\$$ or (post\$ NEAR pain\$) or (postoperative adj4 analgesi \$) or (post-operative adj4 analgesi\$) or ("post-operative analgesi\$")).ti.ab.kw.

6. ((post-surgical adj4 pain\$) or ("post surgical" adj4 pain\$) or (post-surgery adj4 pain\$)).ti.ab.kw.

7. (("pain-relief after surg\$") or ("pain following surg\$") or ("pain control after")).ti.ab.kw.

8. (("post surg\$" or post-surg\$) AND (pain\$ or discomfort)).ti.ab.kw.

9. ((pain\$ adj4 "after surg\$") or (pain\$ adj4 "after operat\$") or (pain\$ adj4 "follow\$ operat\$") or (pain\$ adj4 "follow\$ surg\$")).ti.ab.kw.

10.((analgesi\$ adj4 "after surg\$") or (analgesi\$ adj4 "after operat\$") or (analgesi\$ adj4 "follow\$ operat\$") or (analgesi\$ adj4 "follow\$ surg \$")).ti.ab.kw.

11.OR/4-10

12.clinical trials.sh.

13.controlled clinical trials.sh.

14. randomized controlled trial.sh.

15.double-blind procedure.sh.

16. (clin\$ adj25 trial\$).ab.

17. ((doubl\$ or trebl\$ or tripl\$) adj25 (blind\$ or mask\$)).ab.

18.placebo\$.ab.

19.random\$.ab.

20.0R/12-19

21.3 AND 11 AND 20

\section{Appendix 3. Cochrane CENTRAL search strategy}

1. MESH descriptor celecoxib

2. (celecoxib OR celebrexOR Celebra OR Onsenal):ti.ab.kw.

3. $\mathrm{OR} / 1-2$

4. MESH descriptor PAIN, POSTOPERATIVE

5. ((postoperative adj4 pain\$) or (post-operative adj4 pain\$) or post-operative-pain $\$$ or (post\$ NEAR pain\$) or (postoperative adj4 analgesi \$) or (post-operative adj4 analgesi\$) or ("post-operative analgesi\$")):ti.ab.kw.

6. ((post-surgical adj4 pain\$) or ("post surgical" adj4 pain\$) or (post-surgery adj4 pain\$)):ti.ab.kw.

7. (("pain-relief after surg\$") or ("pain following surg\$") or ("pain control after")):ti.ab.kw.

8. (("post surg\$" or post-surg\$) AND (pain\$ or discomfort)):ti.ab.kw.

9. ((pain\$ adj4 "after surg\$") or (pain\$ adj4 "after operat\$") or (pain\$ adj4 "follow\$ operat\$") or (pain\$ adj4 "follow\$ surg\$")):ti.ab.kw.

10.((analgesi\$ adj4 "after surg\$") or (analgesi\$ adj4 "after operat\$") or (analgesi\$ adj4 "follow\$ operat\$") or (analgesi\$ adj4 "follow\$ surg $\$ ")):$ ti.ab.kw.

11.OR/4-10

12.Limit 11 to Clinical Trials (CENTRAL)

\section{Appendix 4. Glossary}

\section{Categorical rating scale}

The commonest is the five category scale (none, slight, moderate, good or lots, and complete). For analysis numbers are given to the verbal categories (for pain intensity, none $=0$, mild $=1$, moderate $=2$, and severe $=3$, and for relief none $=0$, slight $=1$, moderate $=2$, good or lots $=3$, and complete $=4$ ). Data from different subjects is then combined to produce means (rarely medians) and measures of dispersion (usually standard errors of means). The validity of converting categories into numerical scores was checked by comparison with 
concurrent visual analogue scale measurements. Good correlation was found, especially between pain relief scales using cross-modality matching techniques. Results are usually reported as continuous data, mean or median pain relief or intensity. Few studies present results as discrete data, giving the number of participants who report a certain level of pain intensity or relief at any given assessment point. The main advantages of the categorical scales are that they are quick and simple. The small number of descriptors may force the scorer to choose a particular category when none describes the pain satisfactorily.

\section{Visual analogue scale (VAS)}

Analogue scale: lines with left end labelled 'no relief of pain' and right end labelled 'complete relief of pain', seem to overcome this limitation. Patients mark the line at the point which corresponds to their pain. The scores are obtained by measuring the distance between the no relief end and the patient's mark, usually in millimetres. The main advantages of VAS are that they are simple and quick to score, avoid imprecise descriptive terms, and provide many points from which to choose. More concentration and co-ordination are needed, which can be difficult postoperatively or with neurological disorders.

\section{TOTPAR}

Total pain relief (TOTPAR) is calculated as the sum of pain relief scores over a period of time. If a patient had complete pain relief immediately after taking an analgesic, and maintained that level of pain relief for six hours, they would have a six-hour TOTPAR of the maximum of 24. Differences between pain relief values at the start and end of a measurement period are dealt with by the trapezoidal rule.

\section{SPID}

Summed pain intensity difference (SPID) is calculated as the sum of the differences between the pain scores over a period of time. Differences between pain intensity values at the start and end of a measurement period are dealt with by the trapezoidal rule.

VAS TOTPAR and VAS SPID are visual analogue versions of TOTPAR and SPID.

See 'Measuring pain' in Bandolier's Little Book of Pain, Oxford University Press, Oxford. 2003; pp 7-13 (Moore 2003).

Appendix 5. Summary of outcomes in individual studies: efficacy

\begin{tabular}{|c|c|c|c|c|c|c|}
\hline \multirow[b]{2}{*}{ Study ID } & \multirow[b]{2}{*}{ Treatment } & \multicolumn{3}{|l|}{ Analgesia } & \multicolumn{2}{|c|}{ Rescue medication } \\
\hline & & PI or PR & $\begin{array}{l}\text { Number } \\
\text { with } 50 \% \\
\text { PR }\end{array}$ & $\begin{array}{l}\text { PGE: very } \\
\text { good or ex- } \\
\text { cellent }\end{array}$ & $\begin{array}{l}\text { Median } \\
\text { time to use } \\
\text { (hr) }\end{array}$ & $\begin{array}{l}\text { Number } \\
\text { using }\end{array}$ \\
\hline \multirow{4}{*}{$\begin{array}{l}\text { Malmstrom } \\
1999\end{array}$} & (1) cele $200 \mathrm{mg}, \mathrm{n}=91$ & TOTPAR 6: & (1) $38 / 91$ & At 8 hrs: & (1) 5.1 & In 24 hrs: \\
\hline & (2) rofe $50 \mathrm{mg}, \mathrm{n}=90$ & (1) 9.55 & (4) $2 / 45$ & (1) $26 / 91$ & (4) 1.5 & (1) $71 / 91$ \\
\hline & (3) ibu $400 \mathrm{mg}, \mathrm{n}=46$ & (4) 3.07 & & (4) $3 / 45$ & & (4) $41 / 45$ \\
\hline & (4) placebo, $n=45$ & & & & & \\
\hline \multirow{3}{*}{$\begin{array}{l}\text { Gimbel } \\
2001\end{array}$} & (1) cele $200 \mathrm{mg}, \mathrm{n}=141$ & SPID 6: & (1) $55 / 141$ & No data & $(1)>8$ & At $8 \mathrm{hrs:}$ \\
\hline & (2) hydrocod/paracet $10 / 1000 \mathrm{mg}, \mathrm{n}=136$ & (1) 4.38 & (3) $30 / 141$ & & (3) 3.9 & (1) $62 / 141$ \\
\hline & (3) placebo, $n=141$ & (3) 2.51 & & & & (3) $90 / 141$ \\
\hline \multirow{5}{*}{$\begin{array}{l}\text { Malmstrom } \\
2002\end{array}$} & (1) cele $400 \mathrm{mg}, \mathrm{n}=151$ & TOTPAR 6: & (1) $74 / 151$ & At $8 \mathrm{hrs:}$ & (1) 10.6 & At $24 \mathrm{hrs:}$ \\
\hline & (2) cele $200 \mathrm{mg}, \mathrm{n}=90$ & (1) 10.98 & (2) $32 / 90$ & (1) $62 / 151$ & (2) 6.8 & (1) $99 / 151$ \\
\hline & (3) rofe $50 \mathrm{mg}, \mathrm{n}=150$ & (2) 8.4 & (5) $0 / 45$ & (2) $31 / 90$ & (5) 1.6 & (2) $62 / 90$ \\
\hline & (4) ibu $400 \mathrm{mg}, \mathrm{n}=45$ & (5) 1.04 & & (5) $1 / 45$ & & (5) $44 / 45$ \\
\hline & (5) placebo, $n=45$ & & & $\begin{array}{l}\text { Pts did not } \\
\text { report - as- } \\
\text { sume poor } \\
\text { response }\end{array}$ & & \\
\hline
\end{tabular}


(Continued)

\begin{tabular}{|c|c|c|c|c|c|c|}
\hline $\begin{array}{l}\text { Kellstein } \\
2004\end{array}$ & $\begin{array}{l}\text { (1) cele } 200 \mathrm{mg}, \mathrm{n}=101 \\
\text { (2) lumira } 400 \mathrm{mg}, \mathrm{n}=101\end{array}$ & $\begin{array}{l}\text { TOTPAR 6: } \\
\text { (1) } 6.13\end{array}$ & $\begin{array}{l}\text { (1) } 23 / 101 \\
\text { (4) } 0 / 51\end{array}$ & $\begin{array}{l}\text { No usable } \\
\text { data }\end{array}$ & $\begin{array}{l}\text { (1) } 2.0 \\
\text { (4) } 1.3\end{array}$ & $\begin{array}{l}14.9 \% \\
\text { of whole } \\
\text { group }\end{array}$ \\
\hline & (3) rofe $50 \mathrm{mg}, \mathrm{n}=102$ & (4) 1.4 & & & & \\
\hline
\end{tabular}

\begin{tabular}{|c|c|c|c|c|c|c|}
\hline $\begin{array}{l}\text { Moberly } \\
2007\end{array}$ & $\begin{array}{l}\text { (1) cele } 400 \mathrm{mg}, \mathrm{n}=51 \\
\text { (2) placebo, } \mathrm{n}=52 \\
\text { Also tested: CS- } 706 \text { at } 10,50,100,200 \mathrm{mg}\end{array}$ & $\begin{array}{l}\text { TOTPAR 4: } \\
\text { (1) } 7.2 \\
\text { (2) } 2.4\end{array}$ & $\begin{array}{l}\text { (1) } 25 / 51 \\
\text { (2) } 4 / 51\end{array}$ & $\begin{array}{l}\text { At } 24 \mathrm{hrs} \text { : } \\
\text { (1) } 49 \% \\
\text { (2) } 14 \%\end{array}$ & $\begin{array}{l}(1)>12 \\
\text { (2) } 1.67\end{array}$ & $\begin{array}{l}\text { At } 6 \text { hrs: } \\
\text { (1) } 12 / 51 \\
\text { (2) } 41 / 51\end{array}$ \\
\hline Doyle 2002 & $\begin{array}{l}\text { (1) cele } 200 \mathrm{mg}, \mathrm{n}=74 \\
\text { (2) ibu liquigel } 400 \mathrm{mg}, \mathrm{n}=74 \\
\text { (3) placebo, } \mathrm{n}=26\end{array}$ & $\begin{array}{l}\text { No usable } \\
\text { data }\end{array}$ & No data & $\begin{array}{l}\text { No usable } \\
\text { data }\end{array}$ & $\begin{array}{l}(1)>12 \\
\text { (3) } 2.0\end{array}$ & $\begin{array}{l}\text { At } 12 \mathrm{hrs:} \\
\text { (1) } 30 / 74 \\
\text { (3) } 21 / 26\end{array}$ \\
\hline $\begin{array}{l}\text { Cheung } \\
2007\end{array}$ & $\begin{array}{l}\text { (1) cele } 400 \mathrm{mg}, \mathrm{n}=57 \\
\text { (2) ibu } 400 \mathrm{mg}, \mathrm{n}=57 \\
\text { (3) placebo, } \mathrm{n}=57\end{array}$ & $\begin{array}{l}\text { TOTPAR 6: } \\
\text { (1) } 13.4 \\
\text { (3) } 3.7\end{array}$ & $\begin{array}{l}\text { (1) } 36 / 57 \\
\text { (3) } 5 / 57\end{array}$ & No data & $\begin{array}{l}(1)>24 \\
\text { (3) } 1.85\end{array}$ & $\begin{array}{l}\text { At } 24 \text { hrs: } \\
\text { (1) } 26 / 57 \\
\text { (3) } 49 / 57\end{array}$ \\
\hline Fricke 2008 & $\begin{array}{l}\text { (1) cele } 400 \mathrm{mg}, \mathrm{n}=156 \\
\text { (2) lumira } 400 \mathrm{mg}, \mathrm{n}=156 \\
\text { (3) placebo, } \mathrm{n}=52\end{array}$ & $\begin{array}{l}\text { TOTPAR 6: } \\
\text { (1) } 7.78 \\
\text { (3) } 1.76\end{array}$ & $\begin{array}{l}\text { (1) } 49 / 156 \\
\text { (3) } 0 / 52\end{array}$ & $\begin{array}{l}\text { No usable } \\
\text { data }\end{array}$ & $\begin{array}{l}\text { (1) } 3.8 \\
\text { (3) } 1.3\end{array}$ & $\begin{array}{l}\text { At } 24 \mathrm{hrs} \text { : } \\
\text { (1) } 103 / 156 \\
\text { (3) } 47 / 52\end{array}$ \\
\hline $\begin{array}{l}\text { Manvelian } \\
2012\end{array}$ & $\begin{array}{l}\text { (1) cele } 400 \mathrm{mg}, \mathrm{n}=51 \\
\text { (2) nano-formulated diclofenac } 18 \mathrm{mg}, \mathrm{n} \\
=49 \\
\text { (3) nano-formuated diclofenac } 35 \mathrm{mg}, \mathrm{n}= \\
51 \\
\text { (4) Placebo, } \mathrm{n}=51\end{array}$ & $\begin{array}{l}\text { TOTPAR 4: } \\
\text { (1) } 5.71(4) \\
2.14\end{array}$ & $\begin{array}{l}\text { (1) } 18 / 51 \\
\text { (4) } 3 / 51\end{array}$ & No data & No data & No data \\
\hline IND2-08-03 & $\begin{array}{l}\text { (1) cele } 400 \mathrm{mg}, \mathrm{n}=51 \\
\text { (2) indomethacin } 20 \mathrm{mg}, \mathrm{n}=50 \\
\text { (3) indomethacin } 40 \mathrm{mg}, \mathrm{n}=51 \text { (4) Place- } \\
\text { bo, } n=51\end{array}$ & $\begin{array}{l}\text { No usable } \\
\text { data } \\
\text { TOTPAR } 8 \\
\text { (1) } 14.822 \\
\text { (4) } 3.019\end{array}$ & No data & No data & No data & No data \\
\hline
\end{tabular}

cele - celecoxib; CS-706 - experimental compound; hydrocod/paracet - hydrocodone/paracetamol; ibu - ibuprofen; lumira - lumiracoxib; pts - participants; rofe - rofecoxib

Appendix 6. Summary of outcomes in individual studies: adverse events and withdrawals

Adverse events

Single dose oral celecoxib for acute postoperative pain in adults (Review)

Copyright @ 2019 The Cochrane Collaboration. Published by John Wiley \& Sons, Ltd. 
(Continued)

\begin{tabular}{|c|c|c|c|c|}
\hline Study ID & Treatment & Any & Serious & $\begin{array}{l}\text { Adverse } \\
\text { event }\end{array}$ \\
\hline \multirow{4}{*}{$\begin{array}{l}\text { Malmstrom } \\
1999\end{array}$} & (1) cele $200 \mathrm{mg}, \mathrm{n}=91$ & \multirow{4}{*}{$\begin{array}{l}\text { No useable data } \\
\text { Mostly nausea, vomiting, } \\
\text { headache }\end{array}$} & \multirow[t]{4}{*}{ None reported } & \multirow{4}{*}{$\begin{array}{l}\text { (1) } 0 / 91 \\
\text { (4) } 1 / 45 \text { (ex- } \\
\text { cessive bleed- } \\
\text { ing) }\end{array}$} \\
\hline & (2) rofe $50 \mathrm{mg}, \mathrm{n}=90$ & & & \\
\hline & (3) ibu $400 \mathrm{mg}, \mathrm{n}=46$ & & & \\
\hline & (4) placebo, $n=45$ & & & \\
\hline
\end{tabular}

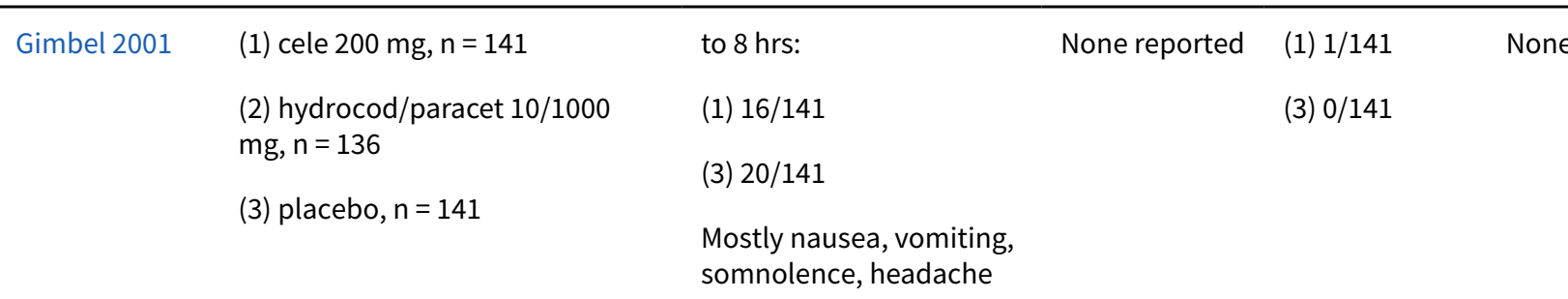

\begin{tabular}{|c|c|c|c|c|c|}
\hline \multirow{5}{*}{$\begin{array}{l}\text { Malmstrom } \\
2002\end{array}$} & (1) cele $400 \mathrm{mg}, \mathrm{n}=151$ & To $24 \mathrm{hrs:}$ & (1) $0 / 151$ & \multirow[t]{5}{*}{ None reported } & \multirow[t]{5}{*}{ None } \\
\hline & (2) cele $200 \mathrm{mg}, \mathrm{n}=90$ & (1) $38 / 151$ & \multirow{3}{*}{$\begin{array}{l}\text { (2) } 1 / 90 \text { (at } \\
\text { post study vis- } \\
\text { it, not relat- } \\
\text { ed to medica- } \\
\text { tion) }\end{array}$} & & \\
\hline & (3) rofe $50 \mathrm{mg}, \mathrm{n}=150$ & (2) $22 / 90$ & & & \\
\hline & (4) ibu $400 \mathrm{mg}, \mathrm{n}=45$ & (5) $12 / 45$ & & & \\
\hline & (5) placebo, $n=45$ & $\begin{array}{l}\text { Mostly nausea and vom- } \\
\text { iting }\end{array}$ & (5) $0 / 45$ & & \\
\hline \multirow[t]{4}{*}{ Kellstein 2004} & (1) cele $200 \mathrm{mg}, \mathrm{n}=101$ & To 24 hrs: & None & \multirow[t]{4}{*}{ None } & \multirow[t]{4}{*}{ None } \\
\hline & (2) lumira $400 \mathrm{mg}, \mathrm{n}=101$ & (1) $20 / 101$ & & & \\
\hline & (3) rofe $50 \mathrm{mg}, \mathrm{n}=102$ & (4) $9 / 51$ & & & \\
\hline & (4) placebo, $n=51$ & & & & \\
\hline
\end{tabular}

\begin{tabular}{|c|c|c|c|c|c|}
\hline Moberly 2007 & $\begin{array}{l}\text { (1) cele } 400 \mathrm{mg}, \mathrm{n}=51 \\
\text { (2) placebo, } n=52 \\
\text { Also tested CS- } 706 \text { at } 10,50,100 \text {, } \\
200 \mathrm{mg}\end{array}$ & $\begin{array}{l}\text { To } 24 \text { hrs: } \\
\text { (1) } 23 / 51 \\
\text { (2) } 27 / 52 \\
\text { Drug-related: (1) } 5 / 51 ;(2) \\
13 / 52\end{array}$ & None & None & $\begin{array}{l}1 \text { placebo pt } \\
\text { had protocol } \\
\text { violation (res- } \\
\text { cue medica- } \\
\text { tion early) - } \\
\text { excluded from } \\
\text { ITT analysis }\end{array}$ \\
\hline Doyle 2002 & $\begin{array}{l}\text { (1) cele } 200 \mathrm{mg}, \mathrm{n}=74 \\
\text { (2) ibu liquigel } 400 \mathrm{mg}, \mathrm{n}=74 \\
\text { (3) placebo, } \mathrm{n}=26\end{array}$ & $\begin{array}{l}\text { To } 12 \text { hrs: } \\
\text { (1) } 5 / 74 \\
\text { (3) } 3 / 26 \\
\text { Most mild to moder- } \\
\text { ate, nausea, vomiting, } \\
\text { headache }\end{array}$ & None & $\begin{array}{l}\text { (1) } 0 / 74 \\
\text { (3) } 0 / 26\end{array}$ & $\begin{array}{l}5 \text { pts ( } 2 \text { cele) } \\
\text { excluded from } \\
\text { analysis due } \\
\text { to protocol vi- } \\
\text { olation, admin } \\
\text { reason, with- } \\
\text { drew consent }\end{array}$ \\
\hline Cheung 2007 & $\begin{array}{l}\text { (1) cele } 400 \mathrm{mg}, \mathrm{n}=57 \\
\text { (2) ibu } 400 \mathrm{mg}, \mathrm{n}=57 \\
\text { (3) placebo, } \mathrm{n}=57\end{array}$ & $\begin{array}{l}\text { To } 24 \text { hrs: } \\
\text { (1) } 29 / 57 \\
\text { (3) } 39 / 57\end{array}$ & $\begin{array}{l}\text { (1) } 1 / 57 \text { (rhab- } \\
\text { domyolysis) } \\
\text { (3) } 0 / 57\end{array}$ & $\begin{array}{l}\text { (1) } 1 / 57 \\
\text { (3) } 3 / 57\end{array}$ & $\begin{array}{l}1 \text { placebo pt } \\
\text { withdrew con- } \\
\text { sent }\end{array}$ \\
\hline
\end{tabular}


(Continued)

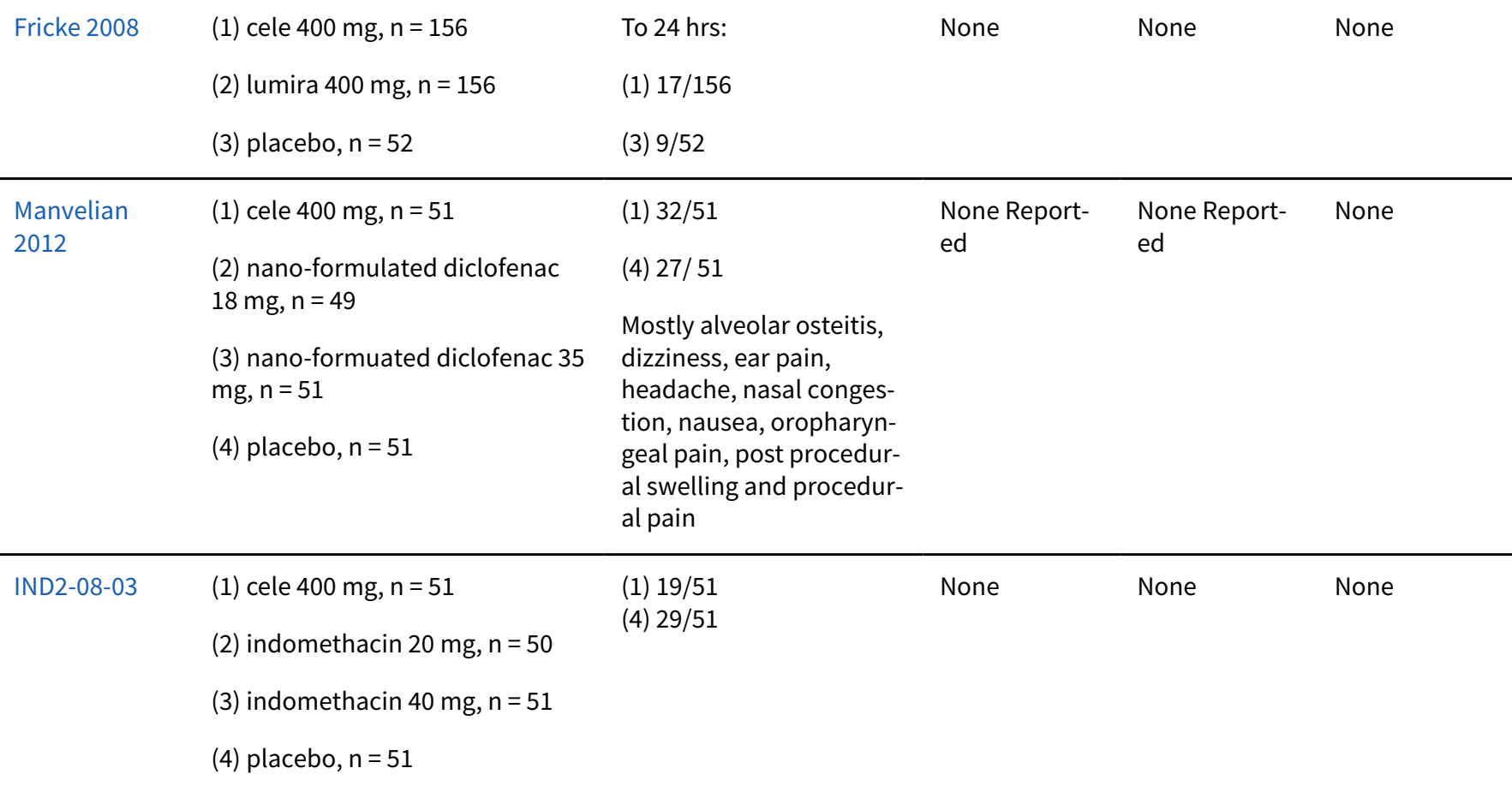

cele - celecoxib; CS-706 - experimental compound; hydrocod/paracet - hydrocodone/paracetamol; ibu - ibuprofen; ITT - intention-totreat; lumira - lumiracoxib; pts - patients; rofe - rofecoxib

WHAT'S NEW

\begin{tabular}{lll}
\hline Date & Event & Description \\
\hline 29 May 2019 & Amended & Contact details updated. \\
\hline 11 October 2017 & Review declared as stable & No new studies likely to change the conclusions are expected. \\
\hline
\end{tabular}

\section{HISTORY}

Protocol first published: Issue 2, 2003

Review first published: Issue 2, 2003

\begin{tabular}{lll}
\hline Date & Event & Description \\
\hline 15 December 2016 & Review declared as stable & See Published notes. \\
\hline 1 June 2016 & Amended & See Published notes. \\
\hline 6 June 2013 & $\begin{array}{l}\text { New citation required but conclusions } \\
\text { have not changed }\end{array}$ & New search, conclusions remain unchanged. \\
\hline 31 May 2013 & New search has been performed & $\begin{array}{l}\text { Searches updated. Two studies, previously identified but without } \\
\text { data available, now provide data. Conclusions unchanged. }\end{array}$
\end{tabular}




\begin{tabular}{ll}
\hline Date & Description \\
\hline & This review now includes 10 studies with data from 599 partici- \\
pants treated with celecoxib $200 \mathrm{mg}, 415 \mathrm{with}$ celecoxib $400 \mathrm{mg}$, \\
and 570 with placebo. This increases the number in both cele- \\
coxib $400 \mathrm{mg}$ and placebo treatments arms by 102.
\end{tabular}

3 January $2012 \quad$ New search has been performed

Searches updated. No new studies with available data identified. Five potentially relevant, completed, but unpublished studies identified; data not yet available. Conclusions unchanged.

\begin{tabular}{|c|c|c|}
\hline 3 January 2012 & $\begin{array}{l}\text { New citation required but conclusions } \\
\text { have not changed }\end{array}$ & $\begin{array}{l}\text { The search for this review update was brought up to date to Jan- } \\
\text { uary } 2012 \text {. }\end{array}$ \\
\hline 24 September 2010 & Amended & Contact details updated. \\
\hline 7 November 2008 & Amended & Further RevMan 5 changes. \\
\hline \multirow[t]{2}{*}{22 July 2008} & $\begin{array}{l}\text { New citation required and conclusions } \\
\text { have changed }\end{array}$ & $\begin{array}{l}\text { This review now contains data from eight studies using celecoxib } \\
400 \mathrm{mg} \text { and } 200 \mathrm{mg} \text { ( } 1380 \text { participants), compared with two ( } 418 \\
\text { participants) at } 200 \mathrm{mg} \text { previously. }\end{array}$ \\
\hline & & $\begin{array}{l}\text { In addition to the proportion of participants with at least } 50 \% \\
\text { pain relief over six hours, the update collected information on } \\
\text { median time to use of rescue medication. This may be a more } \\
\text { useful practical outcome. }\end{array}$ \\
\hline 22 July 2008 & New search has been performed & $\begin{array}{l}\text { This is an update of the original review published in Issue } 2 \text {, } \\
2003 .\end{array}$ \\
\hline
\end{tabular}

\section{CONTRIBUTIONS OF AUTHORS}

$\mathrm{JB}, \mathrm{JR}$, and RAM undertook searches, extracted and analysed the data for the first review.

SD and RAM carried out searches, data extraction, analysis, and writing for both earlier updates.

TW and SD carried out searches, data extraction and analysis, and updated this review. RAM checked all stages.

\section{DECLARATIONS OF INTEREST}

SD and TW have no interests to declare. RAM has consulted for various pharmaceutical companies and received lecture fees from pharmaceutical companies related to analgesics and other healthcare interventions. SD and RAM have received research support from charities, government, and industry sources at various times; no such support was received for this work.

\section{SOURCES OF SUPPORT}

\section{Internal sources}

- Oxford Pain Relief Trust, UK.

General institutional support

\section{External sources}

- No sources of support supplied

\section{NOTES}

At December 2016, this review has been stabilised following discussion with the authors and editors. If appropriate, we will update the review if new evidence likely to change the conclusions is published, or if standards change substantially which necessitate major revisions. New searches in November 2016 did not identify any studies that would affect the conclusions of the review. In one single-dose 
study in dental pain and two multiple-dose studies in bunionectomy, celecoxib $400 \mathrm{mg}$ was used as an active comparator for submicron formulations of diclofenac and indomethacin. Results for celecoxib versus placebo were consistent with the review findings.

\section{IN DEX TERMS}

\section{Medical Subject Headings (MeSH)}

Acute Pain [*drug therapy]; Administration, Oral; Celecoxib; Cyclooxygenase 2 Inhibitors [*administration \& dosage]; Cyclooxygenase Inhibitors [administration \& dosage]; Pain, Postoperative [ ${ }^{*}$ drug therapy]; Pyrazoles [ ${ }^{*}$ administration \& dosage]; Randomized Controlled Trials as Topic; Sulfonamides [*administration \& dosage]

\section{MeSH check words}

Adult; Humans 